\title{
Neuronal $\alpha$-Bungarotoxin Receptors Differ Structurally from Other Nicotinic Acetylcholine Receptors
}

\author{
Fatima Rangwala, Renaldo C. Drisdel, Sergey Rakhilin, Elizabeth Ko, Pramod Atluri, Amy B. Harkins, \\ Aaron P. Fox, Suleiman B. Salman, and William N. Green \\ Department of Pharmacological and Physiological Sciences, University of Chicago, Chicago, IL 60637
}

\begin{abstract}
We have characterized the $\alpha$-bungarotoxin receptors (BgtRs) found on the cell surface of undifferentiated pheochromocytoma (PC12) cells. The PC12 cells express a homogeneous population of $\alpha 7$-containing receptors that bind $\alpha$-Bgt with high affinity $\left(K_{\mathrm{d}}=\right.$ $94 \mathrm{pm})$. The BgtRs mediate most of the response elicited by nicotine, because the BgtR-specific antagonists methyllycaconitine and $\alpha$-Bgt block $\sim 90 \%$ of the whole-cell current. The binding of nicotinic agonists to cell-surface BgtRs was highly cooperative with four different agonists showing Hill coefficients in the range of 2.3-2.4. A similar agonist binding cooperativity was observed for
\end{abstract}

BgtR homomers formed from chimeric $\alpha 7 / 5 \mathrm{HT} 3$ subunits expressed in tsA 201 cells. Two classes of agonist binding sites, in the ratio of $4: 1$ for PC12 cell BgtRs and 3:1 for $\alpha 7 / 5 \mathrm{HT} 3$ BgtRs, were revealed by bromoacetylcholine alkylation of the reduced sites on both PC12 BgtRs and $\alpha 7 / 5 \mathrm{HT} 3 \mathrm{BgtRs}$. We conclude from this data that PC12 BgtRs and $\alpha 7 / 5 \mathrm{HT} 3$ homomers contain at least three distinguishable agonist binding sites and thus are different from other nicotinic receptors.

Key words: nicotine; $\alpha$-bungarotoxin; pheochromocytoma; nicotinic receptors; electrophysiology; pharmacology
Neuronal nicotinic acetylcholine receptors (AChRs) are members of a large family of neurotransmitter-gated ion channels that includes muscle-type AChRs, $\mathrm{GABA}_{\mathrm{A}}$, glycine, and serotonin (5HT3) receptors (for reviews, see Barnard, 1992; Unwin, 1993; Karlin and Akabas, 1995). Muscle-type AChRs are composed of four homologous subunits $(\alpha 1, \beta 1, \gamma$, and $\delta)$ assembled into a pentamer with a stoichiometry of $\alpha 1_{2} \beta 1 \gamma \delta$. Neurons, in contrast to muscle, express a wide array of AChR subtypes, and this heterogeneity has made neuronal AChR isolation and characterization more difficult. Recent molecular cloning studies have identified AChR genes encoding eight ACh binding subunits $(\alpha 2-\alpha 9)$ and three structural subunits $(\beta 2-\beta 4)$ (Role, 1992; Sargent, 1993). These genes have distinct, overlapping patterns of expression in the brain, sensory end organs, and peripheral ganglia, and the different $\alpha$ and $\beta$ subunits contribute to the pharmacologic and functional diversity of neuronal AChRs (Lindstrom et al., 1995; McGehee and Role, 1995; Role and Berg, 1996). Structurally, the best characterized neuronal AChRs are the high-affinity nicotine binding sites found in brain, which are composed predominantly of $\alpha 4$ and $\beta 2$ subunits with a stoichiometry of $\alpha 4_{2} \beta 2_{3}$ (Anand et al., 1991; Cooper et al., 1991).

Another neuronal AChR subtype is the high-affinity $\alpha$ bungarotoxin receptor (BgtR) (Clarke, 1992; Lindstrom et al., 1995). Recently, BgtRs have been shown to be functional (Alkondon and Albuquerque, 1993; Zhang et al., 1994). They are found

\footnotetext{
Received May 30, 1997; revised Aug. 13, 1997; accepted Aug. 21, 1997.

This work was supported by grants from National Institutes of Health (W.N.G., A.P.F.) and Brain Research Foundation (W.N.G.), a Council for Tobacco Research Scholar Award (W.N.G.), and an American Heart Association (Chicago, IL) Senior Fellowship (S.R.). We thank Dr. Richard Burry for the PC12 N21 cell line; Drs. J.-L Eisele, J. Boulter, and J. Lindstrom for the $\alpha 7$ and $\alpha 7 / 5 \mathrm{HT} 3$ cDNAs; and J. Lindstrom for MAb 319. MAb 35 and 270, also developed by J. Lindstrom, were obtained from the Developmental Studies Bank (Johns Hopkins University and University of Iowa). We also thank Christian Wanamaker for help with some of the experiments.

Correspondence should be addressed to Dr. Green, 947 East 58th Street, Chicago, IL 60637.

Copyright (C) 1997 Society for Neuroscience $0270-6474 / 97 / 178201-12 \$ 05.00 / 0$
}

at presynaptic terminals of several synapses where they appear to regulate synaptic vesicle release (McGehee et al., 1995; Alkondon et al., 1996; Gray et al., 1996). A common feature of most BgtRs is that they contain $\alpha 7$ subunits (Schoepfer et al., 1990; Vernallis et al., 1993; Gotti et al., 1994, 1995). $\alpha 7$ subunits when expressed in Xenopus oocytes form functional, Bgt binding homomers (Couturier et al., 1990; Seguela et al., 1993; Peng et al., 1994), raising the possibility that native BgtRs are $\alpha 7$ homomers. However, BgtRs purified from chicken and rat brain preparations appear to consist of one to four different polypeptide subunits (Conti et al., 1985; Kemp et al., 1985; Whiting and Lindstrom, 1987; Hermans-Borgmeyer et al., 1988; Schoepfer et al., 1990; Gotti et al., 1994) with a pharmacology different from the $\alpha 7$ homomers expressed in oocytes (Anand et al., 1993). These data are consistent with BgtRs composed of more than one subunit subtype. By analogy to the muscle-type AChR and the neuronal high-affinity nicotine binding site, this suggested a subunit stoichiometry of two $\alpha 7$ subunits to three structural subunits (Schoepfer et al., 1990; Anand et al., 1993).

The data presented in this paper are not consistent with a BgtR subunit composition of two ligand binding and three structural subunits. BgtRs expressed in PC12 cells were studied and the agonist binding sites of these receptors characterized. To compare the properties of the PC12 cell BgtR with a BgtR of known subunit composition, a heterologously expressed BgtR homomer was also studied. We find that there are at least three, and more likely four or five, distinguishable agonist binding sites on both BgtRs expressed in PC12 cells and the BgtR homomers, and conclude that these neuronal BgtRs differ structurally from other characterized AChRs that have two binding sites.

\section{MATERIALS AND METHODS}

cDNAs. The human $\alpha 7$ cDNA was the gift of Dr. J. Lindstrom (University of Pennsylvania), and the rat $\alpha 7$ cDNA was the gift of Dr. J. Boulter (UCLA). Both constructs were subcloned into the pCB 6 expression vector, the gift of Dr. M. Roth (University of Texas, Southwest), into the $\mathrm{KpN}$-Xba sites. Chick $\alpha 7$ and chick $\alpha 7 /$ mouse 5HT3 cDNA were the gift 
of Dr. J.-L. Eisele (Pasteur Institute). These cDNAs were subcloned into the pMT3 expression vector (Swick et al., 1992), which contains the same cytomeglavirus promoter as pCB 6, in the NotI-XhoI sites.

Cell lines and transfection. The N21 variant of the PC12 cell line was the gift of Dr. R. Burry (Ohio State University). The cells were cultured in DMEM supplemented with 5\% heat-inactivated horse serum, $5 \%$ fetal bovine serum (Hyclone, Logan, UT), 10,000 U/ml of penicillin and streptomycin (Life Technologies, Gaithersburg, MD) maintained at $37^{\circ} \mathrm{C}$ in the presence of $5 \% \mathrm{CO}_{2}$. The cell line stably expressing Torpedo $\alpha_{2} \beta \gamma \delta$ AChRs (Claudio et al., 1987) and the cell line stably expressing $\alpha_{2} \beta \epsilon \delta$ AChRs (Green and Claudio, 1993) were established as described previously.

The cells expressing $\alpha 7 / 5$ HT3 BgtRs were established by the stable transfection of the $\alpha 7 / 5$ HT3 cDNA in pMT3 into tsA 201 cells (Margolskee et al., 1993), which were the gift of Dr. J. Kyle (University of Chicago). The $\alpha 7 / 5 \mathrm{HT} 3 \mathrm{cDNA}$ was transfected along with the hygromycin resistance gene for selection using a calcium phosphate protocol as described previously (Claudio, 1992). The resultant cell line was maintained in DMEM supplemented with $10 \%$ calf serum (Hyclone) and $1000 \mathrm{U} / \mathrm{ml}$ of hygromycin (Calbiochem, La Jolla, CA). The $\alpha 7$ and $\alpha 7 / 5 \mathrm{HT} 3$ cDNAs were also expressed by transiently transfecting the cDNAs into tsA 201 cells using the same calcium phosphate protocol.

In vitro translation. The rat $\alpha 7$ cDNA was subcloned into pBluescript (Stratagene, La Jolla, CA) in the T7 orientation and linearized with $\mathrm{XbaI}$ (New England Biolabs, Beverly, MA). Complementary RNA was transcribed in vitro with T7 polymerase (Boehringer Mannheim, Indianapolis, IN) at $37^{\circ} \mathrm{C}$ for $1 \mathrm{hr}$. The size of the RNA was analyzed on a $0.7 \%$ formaldehyde agarose gel before translation. A total of $0.1 \mathrm{mg}$ of the RNA was translated at $30^{\circ} \mathrm{C}$ for $1 \mathrm{hr}$ in an RNA-free rabbit reticulocyte lysate (Promega, Madison, WI) in the presence of ${ }^{35} \mathrm{~S}$-methionine (Amersham, Arlington Heights, IL; $1000 \mathrm{Ci} / \mathrm{mmol}$ ) and RNasin (Boehringer Mannheim). Post-translational processing of polypeptides was observed using $3 \mu \mathrm{l}$ canine pancreas microsomes (Promega) per $50 \mu \mathrm{l}$ of translation reaction volume. Translated proteins were analyzed by $10 \%$ SDS-PAGE.

Cell-surface ${ }^{125}$ I-Bgt binding. A ${ }^{125} \mathrm{I}$-Bgt binding assay was used to measure the number of cells surface Bgt binding sites. Under our culture conditions in which the cell were not grown on any substrate, both the PC12 and the transfected tsA201 cells were poorly adherent. This property allowed the cells to be removed from confluent cultures simply by applying a gentle fluid stream from a Pasteur pipet. Cells removed from the plates were washed with PBS and incubated at room temperature in PBS containing $10 \mathrm{nM}{ }^{125} \mathrm{I}-\mathrm{Bgt}(140-170 \mathrm{cpm} / \mathrm{fmol}$; NEN) for $1.5-2 \mathrm{hr}$. This incubation time was sufficient to saturate binding. The cells were then washed three times with PBS and counted in a Wallac 1470 automatic gamma counter. Nonspecific binding was estimated by the addition of the indicated competitive ligand during the incubation. To estimate the toxin association rate, ${ }^{125} \mathrm{I}-\mathrm{Bgt}$ was bound to the cell surface at $4^{\circ} \mathrm{C}$ for the incubation times indicated, and the number of cell-surface Bgt binding sites were determined. To estimate the dissociation rate, cell cultures, first bound with ${ }^{125} \mathrm{I}$-Bgt under saturating conditions, were further incubated at $4^{\circ} \mathrm{C}$ for the indicated times in PBS in the absence of ${ }^{125} \mathrm{I}-\mathrm{Bgt}$, and the number of cell-surface Bgt binding sites were determined.

In experiments for which cell-surface ${ }^{125} \mathrm{I}$-Bgt binding was inhibited by several different ligands, only the initial rate of ${ }^{125}$ I-Bgt binding was measured. Cells were first preincubated for 15-30 min with the indicated concentration of ligand, after which the cells were incubated with $4 \mathrm{nM}$ ${ }^{125} \mathrm{I}-\mathrm{Bgt}$ for $15-30 \mathrm{~min}$. The increase in the Bgt association rate during the 15-30 min incubation time was linear (see Figs. $1 C$ and $3 B$ ).

In experiments for which cell-surface ${ }^{125} \mathrm{I}$-Bgt binding sites were immunoprecipitated, ${ }^{125} \mathrm{I}$-Bgt-bound cells were solubilized in $150 \mathrm{~mm} \mathrm{NaCl}$, 5 mm EDTA, 50 mm Tris, pH 7.4, 1\% Triton X-100, 0.02\% NaN3 (lysis buffer) supplemented with the protease inhibitors $2 \mathrm{~mm}$ phenylmethylsulfonyl fluoride, $2 \mathrm{~mm} N$-ethylmaleimide, and $10 \mu \mathrm{g} / \mathrm{ml}$ each chymotrypsin, leupeptin, pepstatin, and tosyl-lysine chloromethyl ketone. Extracts were clarified by centrifugation at $10,000 \times g$ for $30 \mathrm{~min}$. Antibodies were added to the supernatants, and samples were rotated overnight at $4^{\circ} \mathrm{C}$ followed by precipitation with protein G-Sepharose (Pharmacia, Piscataway, NJ). Tubes were centrifuged for $30 \mathrm{sec}$ at $8000 \times g$ and the pellets washed three times with lysis buffer before counting.

Alkylation with bromoACh. After being harvested and washed, cells were resuspended in PBS containing $0.5 \mathrm{~mm}$ dithiothreitol (DTT). Tubes were rotated at room temperature for $30 \mathrm{~min}$, after which cells were washed rapidly three times with PBS. Cells were then rapidly exposed to the indicated concentrations of bromoACh in PBS, incubated for $30 \mathrm{~min}$, washed three times, and subjected to cell-surface ${ }^{125} \mathrm{I}$-Bgt binding under saturating conditions. Similar results were obtained by performing the DTT incubation in the same buffer with $0.3 \mathrm{~mm}$ DTT or in a different buffer ( $150 \mathrm{~mm} \mathrm{NaCl}, 5 \mathrm{~mm}$ EDTA, $50 \mathrm{~mm}$ Tris, $\mathrm{pH} 8.0$ ) with $0.5 \mathrm{~mm}$ DTT (data not shown).

In experiments for which the DTT concentration was varied, cells were washed in $150 \mathrm{~mm} \mathrm{NaCl}, 5 \mathrm{~mm}$ EDTA, $50 \mathrm{~mm}$ Tris, $\mathrm{pH}$ 8.0, and then the DTT incubation was performed in the same buffer with the indicated DTT concentrations. The bromoACh incubation was performed in 150 mM NaCl, 5 mm EDTA, $50 \mathrm{~mm}$ Tris, $\mathrm{pH}$ 7.0, with $300 \mu \mathrm{M}$ bromoACh for the PC12 cells and $10 \mu \mathrm{M}$ bromoACh for the cells expressing the muscle-type AChRs.

Sucrose gradient sedimentation. To distinguish cell-surface PC12 and $\alpha 7 / 5$ HT3 BgtRs on the basis of their size, the receptors, bound with ${ }^{125} \mathrm{I}$-Bgt and solubilized as described above, were sedimented on sucrose gradients. For this procedure, lysates were layered on a $5 \mathrm{ml} \mathrm{5-20 \%}$ linear sucrose gradient prepared in the lysis buffer. Gradients were centrifuged in a Beckman SW 50.1 rotor at $40,000 \mathrm{rpm}$ for $14.25 \mathrm{hr}$ $\left(\omega 2 t=9.0 \times 10^{11}\right)$. Three-hundred microliter fractions were collected from the top of the gradient and counted. The linearity of the gradient was confirmed by measuring the osmolality of each fraction.

Cross-linking of the ${ }^{125}$ I-Bgt-bound BgtRs. BgtRs on the cell surface of PC12 cells and cells expressing $\alpha 7 / 5$ HT3 BgtRs were bound with ${ }^{125}$ IBgt. Cells, resuspended in PBS, were exposed to $2.5 \mathrm{~mm} 3,3^{\prime}$ dithiobissulfosuccinimidylproprionate (DTSSP; Pierce, Rockford, IL) at room temperature for $10 \mathrm{~min}$. This DTSSP concentration and time of incubation were found to saturate the cross-linking between ${ }^{125} \mathrm{I}-\mathrm{Bgt}$ and the receptor. The reaction was stopped by centrifuging cells for $30 \mathrm{sec}$ at $8000 \times$ $g$ and washing once with PBS. The washed pellets were resuspended in lysis buffer and solubilized overnight at $4^{\circ} \mathrm{C}$, followed by centrifugation for $30 \mathrm{~min}$ at $10,000 \times g$ to pellet the unsolubilized debris. To resolve the cross-linked receptor subunits on a gel, a denaturing SDS-polyacrylamide borate buffer system (Gething et al., 1989) was used. Solubilized samples in a $87.3 \mathrm{~mm}$ borate, $87.3 \mathrm{~mm}$ sodium acetate, $\mathrm{pH} 8.5,0.1 \%$ SDS buffer were loaded onto a $3.5 \%$ polyacrylamide gel in the same buffer system. Whole-cell electrophysiology. Undifferentiated PC12 cells were replated to collagen-coated glass coverslips 6 to $18 \mathrm{hr}$ before recording was begun. A single coverslip of cells was removed from the culture media, set into a recording chamber, and perfused with an external $\mathrm{Na}$ solution that contained (in mM): $135 \mathrm{NaCl}, 2 \mathrm{KCl}, 1 \mathrm{MgCl}_{2}, 5 \mathrm{CaCl}_{2}, 12 \mathrm{HEPES}$, and 10 glucose, $\mathrm{pH}=7.3$ (osmolality $\sim 295$ mOsm). Electrodes were coated with Sylgard, fire-polished, and filled with an internal solution that contained (in mM): 120 CsAsp, $5 \mathrm{MgCl}_{2}$, 0.1 EGTA, 40 HEPES, 2 ATP, and $0.3 \mathrm{GTP}, \mathrm{pH}=7.3$ (osmolality $\sim 310 \mathrm{mOsm}$ ). A single PC12 cell was patch-clamped in the whole-cell configuration (Hamill et al., 1981) with an Axopatch-1C amplifier (Axon Instruments, Foster City, CA) at a holding potential of $-80 \mathrm{mV}$. The data were collected at a $500 \mu \mathrm{sec}$ sampling rate and filtered at $2 \mathrm{kHz}$. For rapid application of nicotine or antagonists, the outlet pipe from a fast perfusion system (Adams and List, Westbury, NY) was situated directly adjacent $(\sim 250 \mu \mathrm{m})$ to the cell and rapidly switched $(10-150 \mathrm{msec})$ between different external solutions. For application of nicotine, the perfusion system was primed for $50 \mathrm{msec}$ to clear the small dead volume $\sim 20-30$ sec before the test application. Nicotine (50 $\mu \mathrm{M}$; Sigma, St. Louis, MO) was added to the Na solution (described above) or to an Na solution that also contained either $\alpha$-Bgt $(0.5 \mu \mathrm{M})$ or methyllycaconitine citrate (MLA, $1 \mu \mathrm{M})$. All experiments were performed at room temperature $\left(22-24^{\circ} \mathrm{C}\right)$. Statistical analysis of the data are expressed as mean $(\times) \pm$ SEM, and an independent Student's $t$ test was performed to test statistical significance $(p=0.05)$.

\section{RESULTS}

\section{Bgt binding sites on the surface of PC12 cells}

In this study, we have characterized BgtRs found on the cell surface of undifferentiated cells of the rat PC12 line variant N21 (Burry, 1993). Using ${ }^{125} \mathrm{I}-\mathrm{Bgt}$ to measure the number of Bgtsensitive AChRs (Fig. 1A), each culture expressed 0.45 pmol of Bgt binding sites or 40,000 surface ${ }^{125} \mathrm{I}-\mathrm{Bgt}$ binding sites per cell, because a $6 \mathrm{~cm}$ culture contained on average $7 \times 10^{6}$ cells. Nonspecific binding was determined by the addition of carbachol or unlabeled Bgt, both of which blocked ${ }^{125} \mathrm{I}-\mathrm{Bgt}$ binding almost completely (Fig. 1A). 

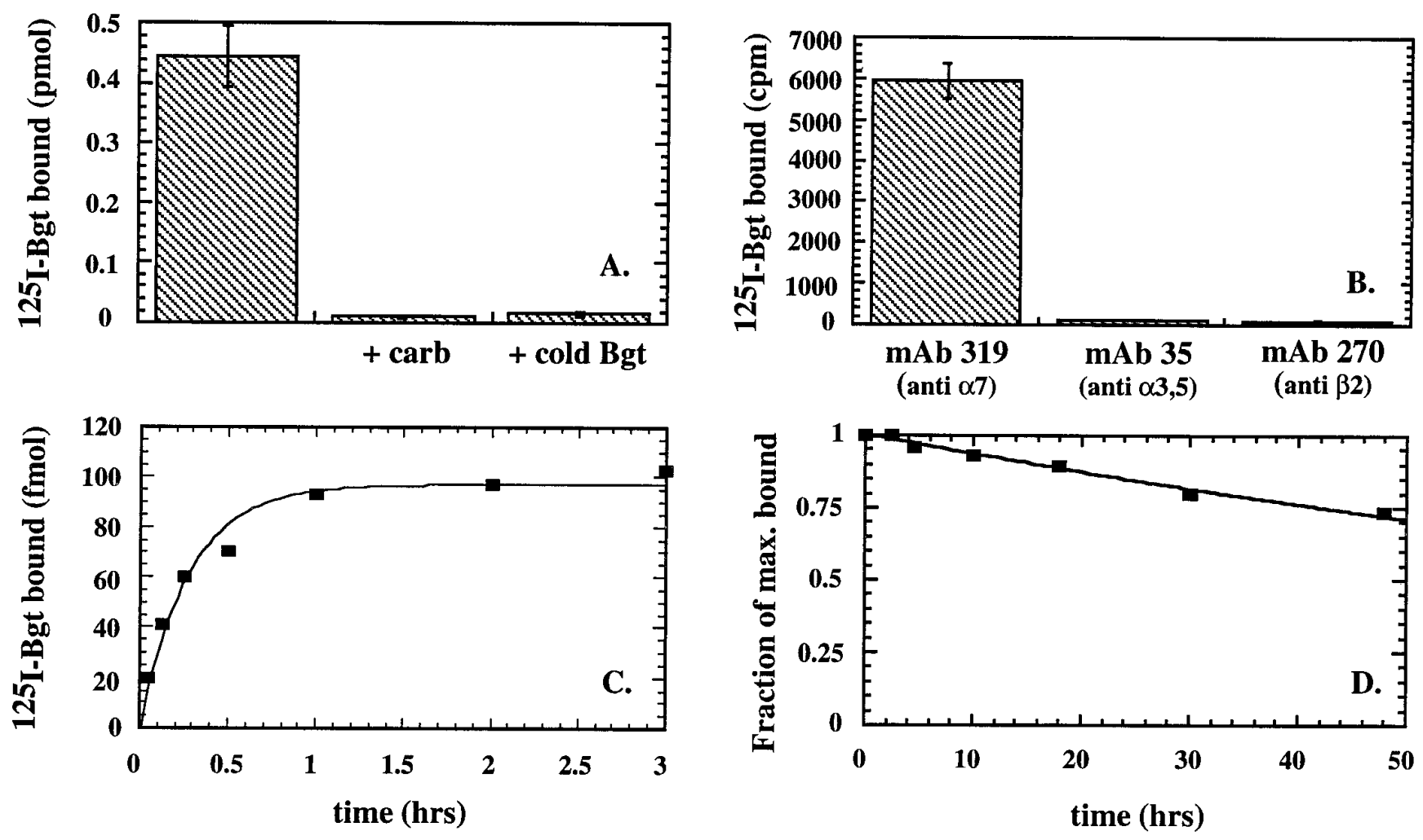

Figure 1. The PC12 BgtR contains $\alpha 7$ subunits and binds Bgt with high affinity. $A$, The cell surface of PC12 cells was bound with ${ }^{125} \mathrm{I}-\mathrm{Bgt}$ in the absence or presence of $10 \mathrm{~mm}$ carbachol or $1 \mathrm{~mm}$ Bgt. The ligands were added to estimate nonspecific binding. In the absence of ligand, the maximum binding was $0.45 \pm 0.05 \mathrm{pmol}\left(\right.$ mean $\pm \mathrm{SD}$ ) obtained from four $6 \mathrm{~cm}$ cultures containing on average $7 \times 10^{6}$ cells. Based on these data, there are $\sim 40,000 \mathrm{Bgt}$ binding sites per cell. $B,{ }^{125}$ I-Bgt-bound, cell-surface BgtRs from PC12 cells are specifically immunoprecipitated by $\alpha 7$-specific mAb 319 , but not by other AChR subunit-specific antibodies. PC12 cells were cell-surface bound with ${ }^{125}$ I-Bgt and precipitated with mAbs specific for $\alpha 7$ subunit, mAb 319 (Schoepfer et al., 1990), $\alpha 3$ and $\alpha 5$ subunit, mAb 35 (Whiting and Lindstrom, 1986), or $\beta 2$ subunit mAb 270 (Whiting et al., 1987). Approximately 40\% of the total cell-surface-labeled receptors $(6000 \pm 400 \mathrm{cpm}$; mean \pm SD from from three $6 \mathrm{~cm}$ cultures $)$ were precipitated by mAb 319 . The counts precipitated by the mAbs specific for the $\alpha 3, \alpha 5$, or $\beta 2$ subunits were indistinguishable from background. $C$, Estimation of the Bgt association rate. PC12 cells were incubated with $10 \mathrm{nM}{ }^{125} \mathrm{I}$-Bgt at $4^{\circ} \mathrm{C}$ for the indicated times. Cell-surface-bound ${ }^{125} \mathrm{I}$-Bgt (in femtomoles) is shown plotted against time of incubation. Each point represents the mean of two $10 \mathrm{~cm}$ cultures. The line through the points represents a least-squares fit to the data of the equation: ${ }^{125} \mathrm{I}$-Bgt bound $=1-\exp \left(-k_{+1} t[\mathrm{Bgt}]\right)$, where $k_{+1}$ is the association rate. The results for all experiments are summarized in Table 1. $D$, Estimation of the Bgt dissociation rate. After PC12 cells were cell-surface-labeled with ${ }^{125} \mathrm{I}$-Bgt, cultures were incubated in the absence of ${ }^{125} \mathrm{I}$-Bgt at $4{ }^{\circ} \mathrm{C}$ for the indicated times. Cell-surface bound ${ }^{125}$ I-Bgt divided by the value at $0 \mathrm{hr}$ (fraction of maximum bound) is shown plotted against time of incubation. Each point represents the mean of two $10 \mathrm{~cm}$ cultures. The line through the points represents a least-squares fit to the data of the equation: fraction of maximum bound $=\exp \left(-k_{-1} t\right)$, where $k_{-1}$ is the dissociation rate. The results for all experiments are summarized in Table 1.

PC12 cells have been shown previously to express $\alpha 3, \alpha 5, \alpha 7$, $\beta 2$, and $\beta 4$ AChR subunits (Rogers et al., 1992; Boyd, 1994; Henderson et al., 1994), which assemble into at least two AChR subtypes. One AChR subtype is the BgtR (Patrick and Stallcup, 1977), but the exact subunit composition remains unknown. The other subtype contains at minimum $\alpha 3$ subunits (Rogers et al., 1992 ) and $\beta 2$ subunits (Whiting et al., 1987). The $\alpha 3 \beta 2$ subtype is expressed poorly in undifferentiated PC12 cells; its expression is upregulated by treating PC12 cells with NGF (Whiting et al., 1987; Henderson et al., 1994). In contrast, approximately equal numbers of BgtRs are expressed in undifferentiated and NGFtreated PC12 cells (Whiting et al., 1987). To minimize the expression of the $\alpha 3 \beta 2$ subtype, the PC12 cells were cultured without NGF. BgtRs on the surface of these cells were specifically immunoprecipitated by the $\alpha 7$-specific monoclonal antibody (mAb) mAb 319 (Schoepfer et al., 1990) but were not recognized by mAbs specific for the AChR subunits $\alpha 3$, $\alpha 5$, or $\beta 2$ (Fig. $1 B$ ). Thus, PC12 BgtRs contain $\alpha 7$ subunits, but do not appear to contain the $\alpha 3$, $\alpha 5$, or $\beta 2 \mathrm{AChR}$ subunits. BgtRs have been shown to contain $\alpha 8$ and $\alpha 9$ subunits (Schoepfer et al., 1990; Elgoyhen et al., 1994). However, $\alpha 8$ subunits appear to be absent from mammalian preparations, and $\alpha 9$ subunits do not form high-affinity BgtRs (Elgoyhen et al., 1994) such as those found in the PC12 cells (see below).

To determine the BgtR affinity for Bgt, we measured the kinetics of ${ }^{125} \mathrm{I}-\mathrm{Bgt}$ binding to intact PC12 cells. The time course of ${ }^{125} \mathrm{I}$-Bgt association and dissociation was determined at $4^{\circ} \mathrm{C}$ to minimize any effects of receptor turnover on these measurements. Although very slow, both ${ }^{125} \mathrm{I}$-Bgt association and dissociation are well fit by single exponentials (Fig. $1 C, D$ ) providing estimates for the association and dissociation rates of $2.5 \pm 0.4 \times 10^{4}$ $\mathrm{M}^{-1} \cdot \mathrm{sec}^{-1}$ and $2.3 \pm 0.1 \times 10^{-6} \cdot \mathrm{sec}^{-1}$, respectively, and a dissociation constant $\left(K_{\mathrm{d}}\right)$ of $94 \mathrm{pm}$. The results are summarized in Table 1.

\section{Heterologous expression of BgtR homomers}

To determine the subunit composition of the PC12 cell BgtRs, we attempted to compare them with BgtRs of known subunit composition expressed in a similar environment. Specifically, $\alpha 7$ subunits were transfected into cultured cell lines to express cell 
Table 1. Estimates of the association rates, dissociation rates, and dissociation constants of Bgt binding to PC12 and $\alpha 7 / 5 \mathrm{HT}_{3}$ BgtRs

\begin{tabular}{llll} 
Cell line & $k_{+1}\left(\mathrm{M}^{-1} \mathrm{sec}^{-1}\right)^{a}$ & $k_{-1}\left(\mathrm{sec}^{-1}\right)^{a}$ & $K_{d}(\mathrm{M})^{b}$ \\
\hline $\mathrm{PC} 12$ & $(2.5 \pm 0.4) \times 10^{4}$ & $(2.3 \pm 0.1) \times 10^{-6}$ & $9.2 \times 10^{-11}$ \\
$\alpha 7 / 5 \mathrm{HT}_{3}$ & $(3.9 \pm 1.1) \times 10^{4}$ & $(2.8 \pm 0.4) \times 10^{-6}$ & $7.2 \times 10^{-11}$
\end{tabular}

${ }^{a}$ Values represent the mean SD from three different determinations.

${ }^{b}$ The dissociation constant $\left(K_{d}\right)$ for each receptor type was calculated from the ratio of $k_{-1} / k_{+1}$.

surface BgtRs. Unfortunately, our efforts met with limited success. Figure $2 A$ graphs the number of Bgt binding sites found on the cell surface in an experiment in which chicken, rat, and human $\alpha 7$ cDNAs, cloned into appropriate expression vectors, were transfected transiently into tsA 201 cells. Transfection of the chicken and human $\alpha 7$ subunit reproducibly yielded Bgt sites only two- to three-fold higher than background, whereas the rat $\alpha 7$ subunit transfection was indistinguishable from background. In other experiments, $\alpha 7$ cDNAs were subcloned into several different expression vectors and were transfected, either transiently or stably, into a variety of different cell lines including National Institutes of Health 3T3 cells, mouse L cells, QT-6 cells, and HEK 293 cells. Again, no significant expression was observed (data not shown). The lack of rat $\alpha 7$ expression cannot be explained by an error within the open reading frame (ORF), because this subunit, when expressed by in vitro translation techniques, resulted in a product of appropriate size. The translated subunit was smaller, $\sim 48 \mathrm{kDa}$, when the ${ }^{35} \mathrm{~S}$-methionine-labeled rat $\alpha 7$ subunit was translated in the absence (Fig. $2 B$, lane $A$ ) of microsomes in comparison with the larger, $\sim 54 \mathrm{kDa}$ subunit obtained in the presence of microsomes (Fig. $2 B$, lane $B$ ). The larger size of the subunit translated in the presence of microsomes indicates that the subunit is $N$-linked glycosylated.

In marked contrast to the low level of expression obtained by transfecting native $\alpha 7$ subunits, BgtR expression levels 100 -fold larger were observed after transiently transfecting an $\alpha 7 / 5 \mathrm{HT} 3$ chimeric subunit cDNA (Fig. $2 A$ ) consisting of the N-terminal half of the chicken $\alpha 7$ subunit and the $\mathrm{C}$-terminal half of the mouse 5HT3 receptor subunit (Eisele et al., 1993). Previous studies of the $\alpha 7 / 5 \mathrm{HT} 3$ chimera indicate that this BgtR displays pharmacologic properties similar to those of either native BgtRs or to BgtRs resulting from the expression of $\alpha 7$ subunits in Xenopus oocytes (Eisele et al., 1993; Corringer et al., 1995). We used the $\alpha 7 / 5 \mathrm{HT} 3 \mathrm{BgtR}$ homomer in our study to compare the properties of PC12 BgtRs with a BgtR of known subunit composition. A tsA201-derived cell line was established that stably expresses $\alpha 7 / 5$ HT3 homomers. Confluent cultures, which contained on average $3 \times 10^{6}$ cells per culture, expressed 2.5 pmol of surface Bgt binding sites under saturating conditions (Fig. $3 A$ ) corresponding to 500,000 surface ${ }^{125} \mathrm{I}$-Bgt binding sites per cell.

The affinity of the $\alpha 7 / 5 \mathrm{HT} 3$ homomer for Bgt was determined by measuring the kinetics of ${ }^{125} \mathrm{I}-\mathrm{Bgt}$ binding to intact cells. The estimated association and dissociation rates are $3.9 \pm 1.1 \times 10^{4}$ $\mathrm{M}^{-1} \cdot \mathrm{sec}^{-1}$ and $2.8 \pm 0.4 \times 10^{-6} \cdot \mathrm{sec}^{-1}$, respectively (Fig. 3B, C), with a $K_{\mathrm{d}}$ of $74 \mathrm{pm}$. The results are summarized in Table 1 . The affinity of the $\alpha 7 / 5 \mathrm{HT} 3$ homomer for Bgt is almost identical to that of the native PC12 BgtR.

\section{PC12 BgtRs and $\alpha 7 / 5 \mathrm{HT} 3$ homomers are similar in size}

Two different experiments were performed to determine structural features of the PC12 BgtRs and the $\alpha 7 / 5 \mathrm{HT} 3$ homomers. First, the cell-surface, ${ }^{125} \mathrm{I}$-Bgt-bound receptors were solubilized

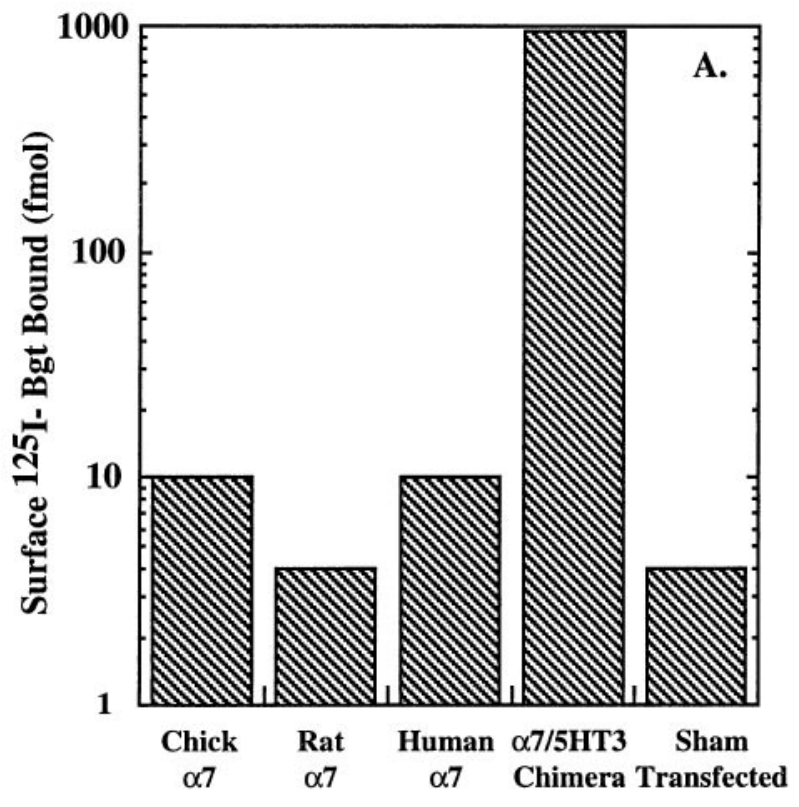

B.

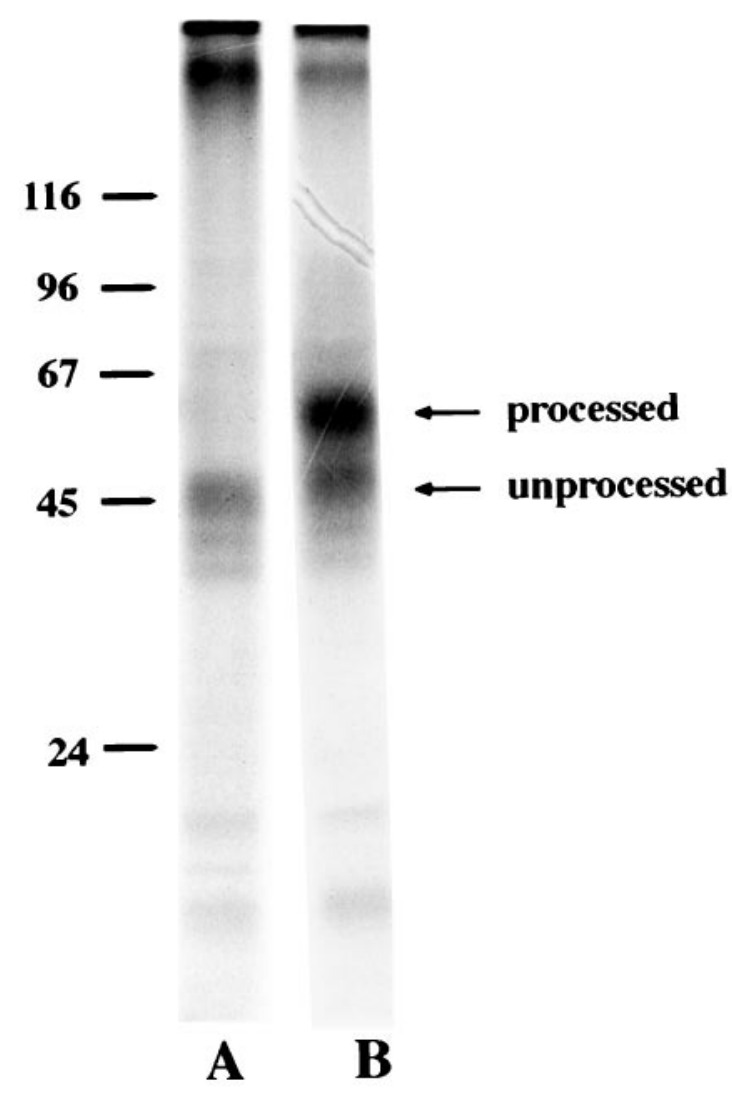

Figure 2. The failure to express $\alpha 7$ subunit homomers. $A$, tsA201 cells were transfected with $5 \mu \mathrm{g}$ of chick, rat, or human $\alpha 7 \mathrm{cDNAs}$ or the $\alpha 7 / 5$ HT3 chimeric cDNA, all in cytomegalovirus-based vectors. Two days after transfection, cells were assayed for cell-surface ${ }^{125} \mathrm{I}$-Bgt binding. Only cells transfected with the $\alpha 7 / 5 \mathrm{HT} 3$ construct showed a sizable increase in cell-surface BgtR expression. Nonspecific ${ }^{125} \mathrm{I}$-Bgt binding was measured by ${ }^{125}$ I-Bgt binding to sham transfected tsA201 cells. $B$, Rat $\alpha 7$ cDNA was translated in vitro with ${ }^{35} \mathrm{~S}$-methionine and labeled in the absence (lane $A$ ) or presence (lane $B$ ) of canine pancreatic microsomes and analyzed on $10 \%$ SDS-PAGE. 
and subjected to density gradient sedimentation. Both receptors migrate as single peaks on the sucrose gradients, with the PC12 cell BgtRs sedimenting at $10 \mathrm{~S}$ and the $\alpha 7 / 5 \mathrm{HT} 3$ homomers at 9 $\mathrm{S}$ (Fig. $4 A$ ). The sedimentation of $\alpha 7 / 5 \mathrm{HT} 3$ homomers was indistinguishable from that for cell-surface Torpedo AChRs, which sediment in a $9 \mathrm{~S}$ peak and were run in a parallel gradient as a standard. The data indicate that the $\alpha 7 / 5 \mathrm{HT} 3$ homomers are pentamers, approximately the same size as the Torpedo AChRs, which have an estimated molecular weight of $\sim 270 \mathrm{kDa}$ (Popot and Changeux, 1984). The molecular weight of an $\alpha 7 / 5$ HT3 subunit pentamer is virtually identical, $269 \mathrm{kDa}$, as estimated from the $\alpha 7 / 5 \mathrm{HT} 3$ subunit ORF (53.8 $\mathrm{kDa})$.

Second, the molecular weights of the PC12 BgtR and the $\alpha 7 / 5$ HT3 homomer were estimated. Cell-surface receptor subunits were cross-linked together and with ${ }^{125} \mathrm{I}$-Bgt using 3,3'DTSSP. The cross-linked complexes were run on a $3.5 \%$ borateacetate gel to resolve the high molecular weight complexes (Fig. $4 B)$. At saturating concentrations of DTSSP, single bands were observed on the gel for both ${ }^{125} \mathrm{I}-\mathrm{Bgt}$ cross-linked receptors. The cross-linking was very efficient, as shown by the small amount of unincorporated ${ }^{125} \mathrm{I}-\mathrm{Bgt}(8 \mathrm{kDa})$ in the gel dye front relative to cross-linked ${ }^{125} \mathrm{I}-\mathrm{Bgt}$. The observation that PC12 BgtRs produced a single band on the gel when labeled and cross-linked provides good evidence for a single homogeneous population of receptors. Based on the size of the standards (Fig. $4 B$ ), the PC12 BgtR has a molecular weight of $\sim 300 \mathrm{kDa}$ and the $\alpha 7 / 5 \mathrm{HT} 3$ homomer a molecular weight of $\sim 260 \mathrm{kDa}$, in agreement with the density gradient sedimentation measurements. Figure $4 B$ provides additional evidence that the $\alpha 7 / 5 \mathrm{HT} 3$ homomer exists in pentameric form, because the measured molecular weight is similar to the estimated molecular weight of the $\alpha 7 / 5 \mathrm{HT} 3$ pentamer $(269 \mathrm{kDa})$. If the PC12 BgtR is also a homomeric pentamer, its calculated molecular weight predicts a subunit in the range of $\sim 60 \mathrm{kDa}$, which is similar to previous estimates of the molecular weight of mature $\alpha 7$ subunits (Schoepfer et al., 1990; Anand et al., 1993; Gotti et al., 1994). The molecular weight of the PC12 BgtR is consistent with it being an $\alpha 7$ homomer, but does not exclude the possibility that it contains other subunits.

\section{PC12 BgtR current response to nicotine}

To test whether the PC12 BgtRs are functional, the whole-cell current response to nicotine was measured. Rapid application of nicotine to undifferentiated PC12 cells elicited a current that activated rapidly and then desensitized (Fig. 5). Figure $5 \mathrm{~A}$ shows the current response observed during a $10 \mathrm{sec}$ application of nicotine $(50 \mu \mathrm{M})$ to a cell that was voltage-cell-clamped at -80 $\mathrm{mV}$. The rate of desensitization was approximately comparable with that observed for rat BgtRs in cultured hippocampal neurons (Alkondon and Albuquerque, 1993), but was much slower than for chick ciliary ganglion BgtRs (Zhang et al., 1994). Two BgtRspecific antagonists, Bgt and MLA (Ward et al., 1990; Alkondon et al., 1992), were used to block the whole-cell currents to determine whether the currents observed resulted from the activation of BgtRs. Bgt blocked most of the nicotine-induced current response (Fig. 5B). The mean block of the nicotine-induced current response by $500 \mathrm{~nm}$ Bgt was $91 \%$ (Fig. 5C) and was never observed to reverse, which is consistent with the slow dissociation rate measured by ${ }^{125} \mathrm{I}-\mathrm{Bgt}$ binding (Fig. $1 D$ ). Although Bgt binds to $\mathrm{PC} 12$ cells with a very high affinity $(94 \mathrm{pM})$, the association rate is extremely slow (Fig. 1C). Based on our measurement of the association rate from the ${ }^{125} \mathrm{I}$-Bgt-binding measurements (Table 1), inhibition of the current response by $500 \mathrm{~nm}$ Bgt should take
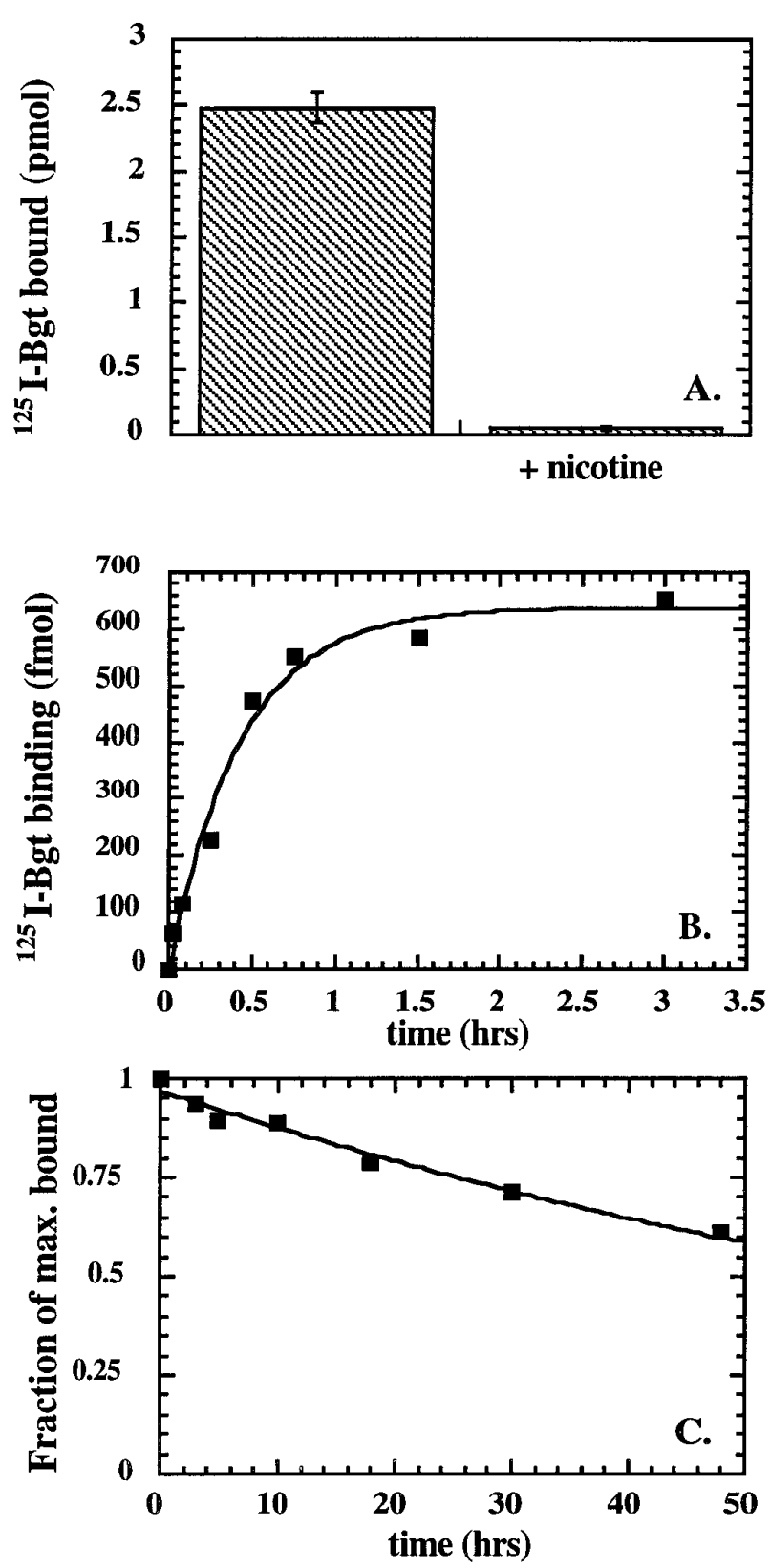

Figure 3. The Bgt binding site of the $\alpha 7 / 5 \mathrm{HT} 3$ homomer. $A$, Cells stably expressing the $\alpha 7 / 5 \mathrm{HT} 3$ subunit were cell-surface labeled with ${ }^{125} \mathrm{I}$-Bgt in the absence or presence of $100 \mu \mathrm{M}$ nicotine. Nicotine was added to estimate nonspecific binding. In the absence of nicotine, the maximum binding was $2.5 \pm 0.1 \mathrm{pmol}$ (mean $\pm \mathrm{SD}$ ) obtained from four $6 \mathrm{~cm}$ cultures containing on average $3 \times 10^{6}$ cells. Based on these data, there are $\sim 500,000 \mathrm{Bgt}$ sites per cell. $B$, Estimation of the Bgt association rate. Cells stably expressing the $\alpha 7 / 5 \mathrm{HT} 3$ subunit were incubated with $20 \mathrm{nM}{ }^{125} \mathrm{I}-\mathrm{Bgt}$ at $4^{\circ} \mathrm{C}$ for the indicated times. Cell-surface-bound ${ }^{125} \mathrm{I}$-Bgt (in femtomoles) is shown plotted versus time of incubation. Each point represents the mean of two 6 $\mathrm{cm}$ cultures. The line through the points represents a least-squares fit to the data of the equation: ${ }^{125} \mathrm{I}-\mathrm{Bgt}$ bound $=1-\exp \left(-k_{+1} t[\mathrm{Bgt}]\right)$, where $k_{+1}$ is the association rate. The results for all experiments are summarized in Table 1. $C$, Estimation of the Bgt dissociation rate. After cells stably expressing the $\alpha 7 / 5 \mathrm{HT} 3$ subunit were cell-surface labeled with ${ }^{125} \mathrm{I}$-Bgt, cultures were incubated in the absence of ${ }^{125} \mathrm{I}$-Bgt at $4^{\circ} \mathrm{C}$ for the indicated times. Cell-surface-bound ${ }^{125} \mathrm{I}$-Bgt divided by the value at $0 \mathrm{hr}$ (fraction of maximum bound) is shown plotted against time of incubation. Each point represents the mean of two $6 \mathrm{~cm}$ cultures. The line through the points represents a least-squares fit to the data of the equation: fraction of maximum bound $=\exp \left(-k_{-1} t\right)$, where $k_{-1}$ is the dissociation rate. The results for all experiments are summarized in Table 1. 


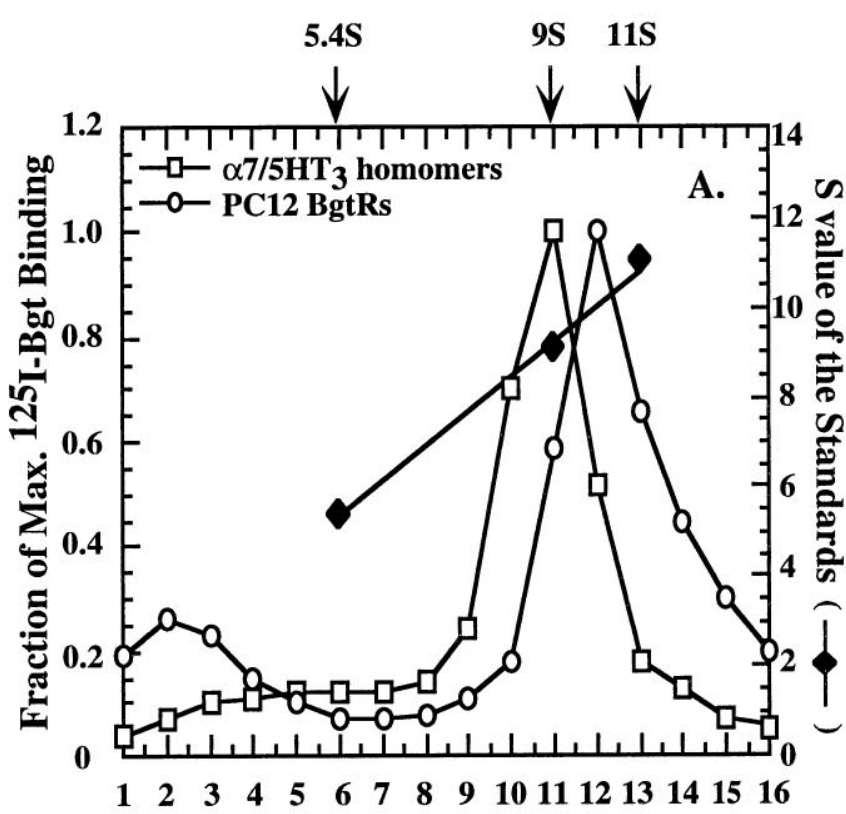

Fraction \#

B.

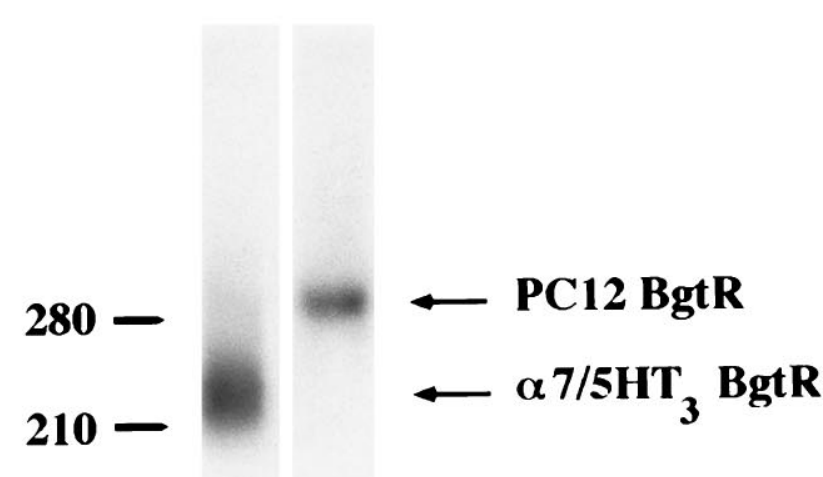

$140-$

$70-$

Dye front several minutes. The time-dependent decrease of the current response after the application of $500 \mathrm{nM} \mathrm{Bgt}$ is consistent with this prediction (Fig. 5D). The Bgt association rate constant calculated from the exponential decay of the current response after application of Bgt is $0.7 \times 10^{4} \mathrm{M}^{-1} \mathrm{sec}^{-1}$. That the rate constant is somewhat slower than that obtained from binding measurements may be attributable to competition with the nicotine used to elicit the response (Fig. 6). MLA also blocked most of the nicotineinduced current response $(88 \%)$, and its block was at least partially reversible (Fig. $5 E, F$ ). The block by both Bgt and MLA demonstrates that the PC12 BgtRs are functional channels and mediate most of the nicotine-induced current response in these undifferentiated cells.

\section{Agonist binding to BgtRs indicates three or more sites per BgtR}

To explore more fully the pharmacologic properties of the BgtRs, we characterized the competition between different cholinergic agonists and ${ }^{125} \mathrm{I}-\mathrm{Bgt}$ binding by measuring the inhibition of the initial rate of ${ }^{125} \mathrm{I}-\mathrm{Bgt}$ binding to $\mathrm{PC} 12 \mathrm{BgtRs}$ (Fig. 6 $A$ ) and $\alpha 7 / 5$ HT3 homomers (Fig. $6 B$ ). Based on the measured $\mathrm{IC}_{50}$ values (Table 2), the order of relative affinities of the PC12 BgtR for the different agonists is nicotine $>$ cytisine $>$ carbachol $>$ ACh. The agonist rank order for the $\alpha 7 / 5 \mathrm{HT} 3$ homomers, nicotine $>$ cytisine $>\mathrm{ACh}>$ carbachol, was different than that for the PC12 BgtRs. In particular, the $\mathrm{IC}_{50}$ value for carbachol was 30 -fold smaller for PC12 BgtRs than for $\alpha 7 / 5 \mathrm{HT} 3$ homomers.

Hill coefficients provide a measure of the degree of cooperativity between different agonist binding sites. Surprisingly, the BgtR found in PC12 cells exhibited Hill coefficients for the agonist ligands tested between 2.3 and 2.4 (Table 2). The $\alpha 7 /$ 5 HT3 homomer Hill coefficients were similar and fell in the range of 2.1 to 2.6 (Table 2). When the same protocol was performed on cell-surface muscle-type AChRs, which have two ligand binding sites, the Hill coefficient for carbachol was 1.5 (Table 2), similar to previous measurements (Claudio et al., 1987; Sine and Claudio, 1991). A Hill coefficient $>2$ indicates that both PC12 BgtRs and $\alpha 7 / 5$ HT3 homomers have at least three agonist binding sites per receptor.

To characterize further the number of agonist binding sites per receptor, we searched for probes that could distinguish among the

Figure 4. The size of PC12 and $\alpha 7 / 5 \mathrm{HT} 3$ BgtRs. $A$, Sucrose gradient sedimentation profiles of cell-surface PC12 (open circles) and $\alpha 7 / 5 \mathrm{HT} 3$ (open squares) BgtRs. Solubilized cell-surface receptors bound with ${ }^{125} \mathrm{I}$ Bgt were subjected to sucrose gradient sedimentation (5-20\%). Both receptors migrate as single peaks, $10 \mathrm{~S}$ for the PC12 BgtRs and $9 \mathrm{~S}$ for the $\alpha 7 / 5$ HT3 BgtRs. The amount of ${ }^{125} \mathrm{I}$-Bgt binding was normalized by dividing by the cpm in the peak fraction, $10,387 \mathrm{cpm}$ for the PC12 BgtRs (fraction 12) and 33,269 $\mathrm{cpm}$ for the $\alpha 7 / 5 \mathrm{HT} 3 \mathrm{BgtRs}$ (fraction 11). The fraction of the maximum ${ }^{125} \mathrm{I}$-Bgt binding (left $\mathrm{y}$-axis) for the two receptors is plotted for each gradient fraction. Also plotted are the $\mathrm{S}$ values (right y-axis) of the peak fractions ( $x$-axis) of each of the three standards (solid diamonds): alkaline phosphatase $(5.4 S)$, cell-surface Torpedo AChRs $(9 S)$, and catalase $(11 S)$, which were run on gradients in parallel with the BgtRs. The peak fraction $S$ values were determined from the plotted linear regression line through the $S$ values of standards. $B$, Cellsurface PC12 and $\alpha 7 / 5 \mathrm{HT} 3 \mathrm{BgtR}$ subunits cross-linked together and to ${ }^{125}$ I-Bgt. Cell-surface receptors bound with ${ }^{125} \mathrm{I}$-Bgt were cross-linked by DTSSP so that both receptor subunits and ${ }^{125} \mathrm{I}$-Bgt were covalently linked. Cross-linked complexes were run on SDS-PAGE in a borate-acetate buffer system. Standards were cross-linked complexes of hemocyanine: monomer, $70 \mathrm{kDa}$; dimer, $140 \mathrm{kDa}$; trimer, $210 \mathrm{kDa}$; tetramer, $280 \mathrm{kDa}$. Relative to the standards shown, the estimated molecular weight of the $\mathrm{PC} 12 \mathrm{BgtR}$ is $300 \mathrm{kDa}$ and of the $\alpha 7 / 5 \mathrm{HT} 3 \mathrm{BgtR}$ is $260 \mathrm{kDa}$. 

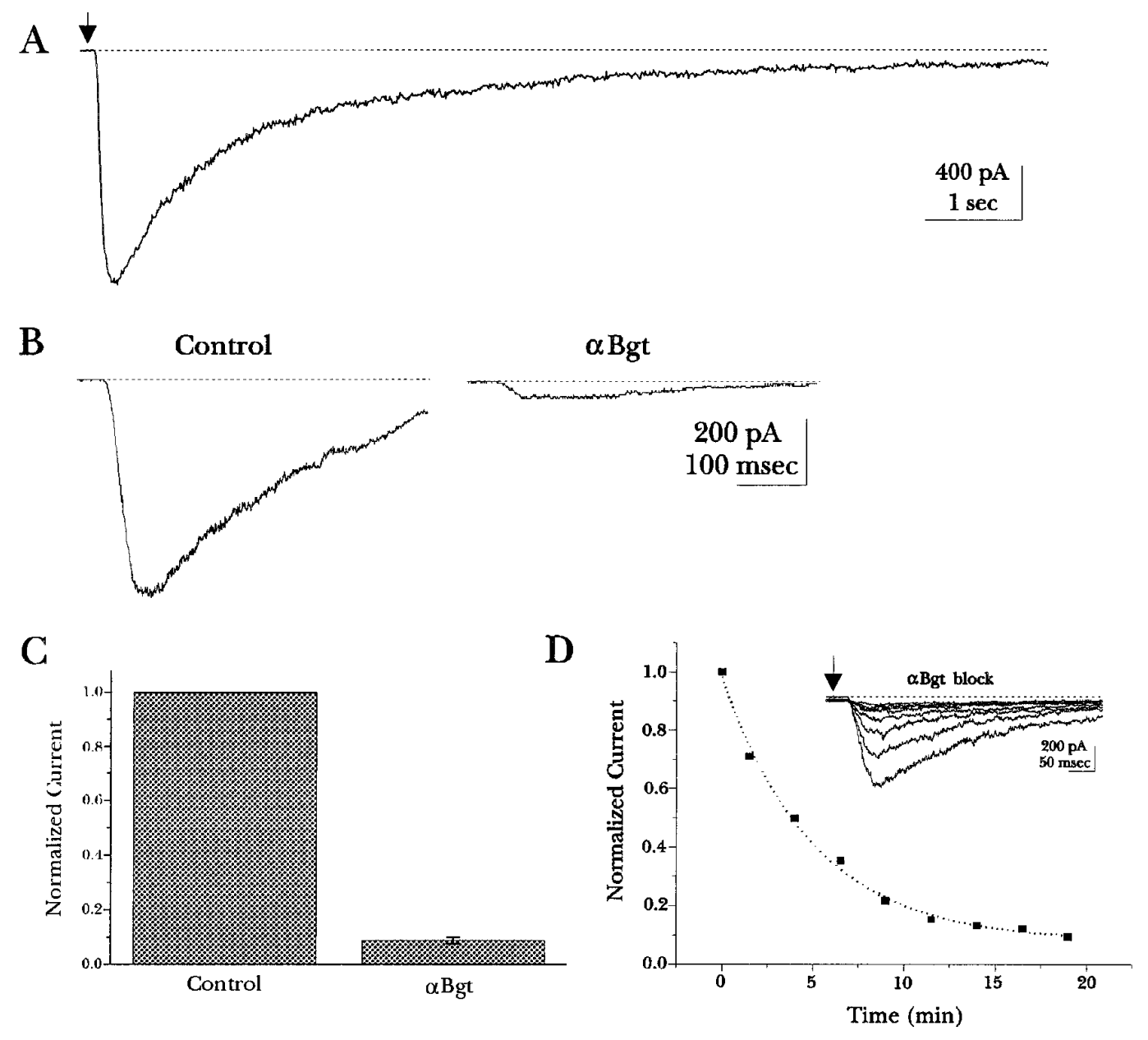
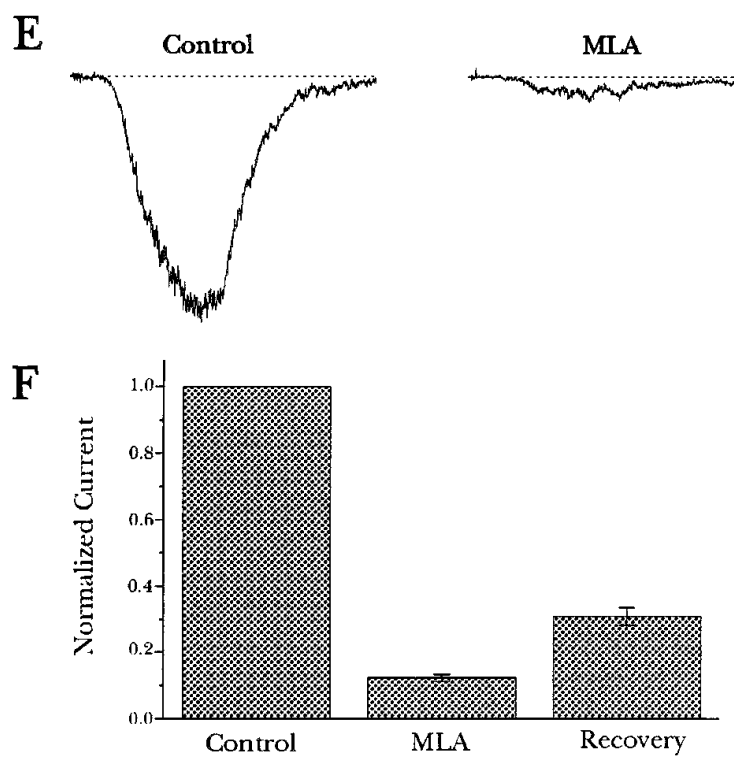

different BgtR sites. Previously, antagonists have been used to distinguish among AChR ligand binding sites. In particular, curare binds to the two muscle-type $\mathrm{AChR}$ sites with an $\sim 100$-fold difference in affinity (Neubig and Cohen, 1979; Sine and Taylor, 1981). Using the same protocol described above for the agonists, the competition between D-tubocurarine (dTC) and ${ }^{125} \mathrm{I}-\mathrm{Bgt}$ was

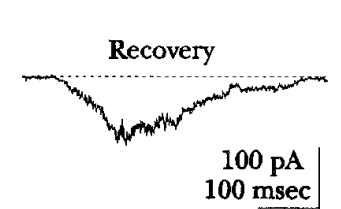

Figure 5. Whole-cell currents elicited by nicotine application in undifferentiated PC12 cells. $A$, The current is shown in response to rapid application of $50 \mu \mathrm{M}$ nicotine, which was applied at the arrow and continued for $10 \mathrm{sec}$. The cell was voltage-clamped at a holding potential of $-80 \mathrm{mV}$. $B$, The current response to $50 \mu \mathrm{M}$ nicotine before and after application of $500 \mathrm{~nm} \mathrm{Bgt} \mathrm{for} 12 \mathrm{~min}$ is shown. Nicotine was applied for $200 \mathrm{msec}$ in each trace. $C$, The fraction of peak current, elicited by nicotine, is plotted, which remains after application of $500 \mathrm{~nm}$ Bgt for 10-20 min. On average, the peak current was reduced to $8.8 \pm 1.2 \%$ of the current measured in the absence of Bgt (Control) for 5 cells. $D$, The fraction of peak current that remains after application of $500 \mathrm{~nm} \mathrm{Bgt}$ as a function of time is plotted. Currents were normalized in amplitude to the first application of nicotine (inset currents). The dotted line represents the fit of a single exponential function to the data with a time constant of $5 \mathrm{~min}$. $E$, The current response to $50 \mu \mathrm{M}$ nicotine before and after application of $1 \mu \mathrm{M}$ MLA for $5 \mathrm{~min}$ is shown. Nicotine was applied for $200 \mathrm{msec}$ in each trace. There was partial recovery of the current response after 7 min of wash. $F$, The fraction of peak current that remains after application of $1 \mu \mathrm{M}$ MLA for 5 to $7 \mathrm{~min}$ is plotted. The peak current was reduced to $12.3 \pm 1.1 \%$ of the current measured in the absence of MLA (Control) for four cells. The peak current reverses to $30.8 \%$ of the control current after 7-10 min of wash after the MLA application. 

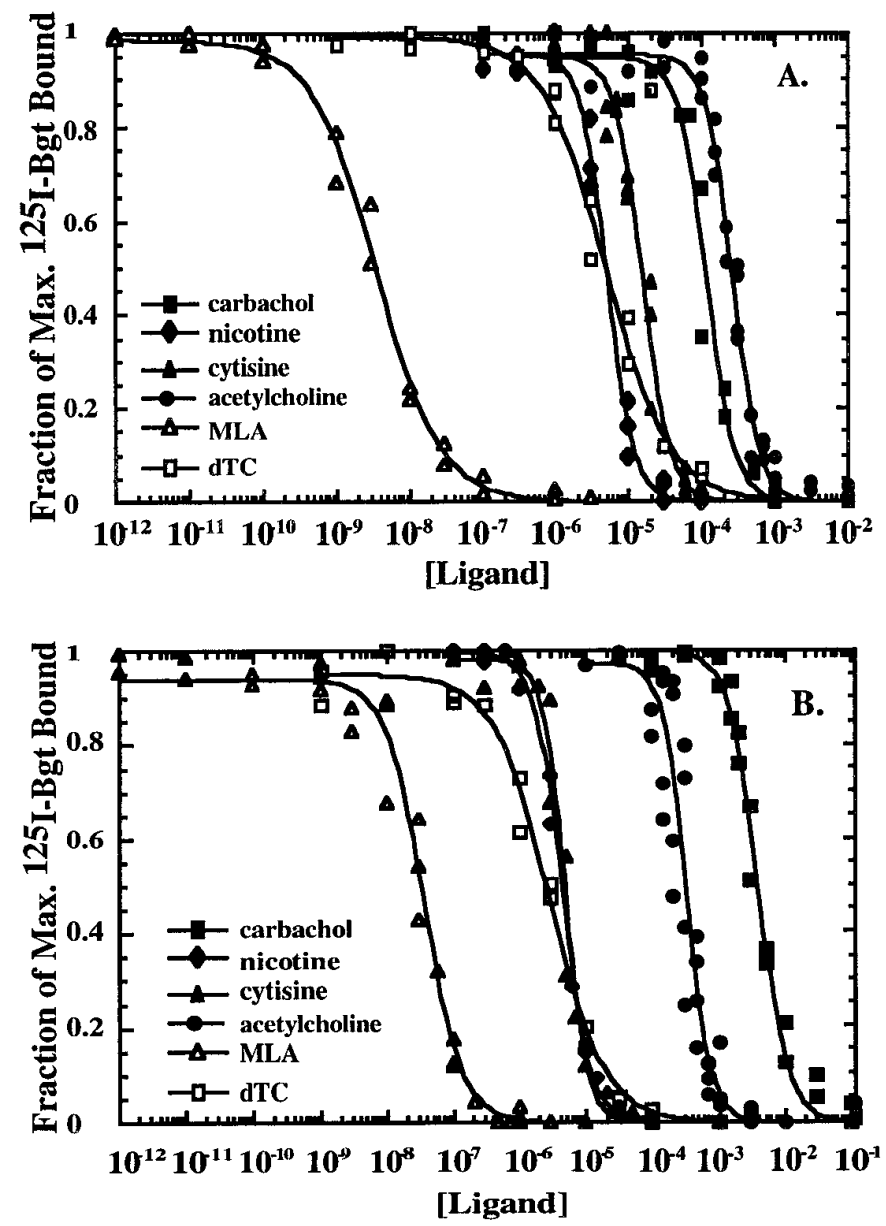

Figure 6. Inhibition of cell-surface Bgt binding by different ligands. $A$, Inhibition of the initial rate of ${ }^{125} \mathrm{I}-\mathrm{Bgt}$ binding to cell-surface PC12 BgtRs by the agonists ACh (solid circle), carbachol (solid square), nicotine (solid diamond), cytisine (solid triangle), and the antagonists MLA (open triangle) and dTC (open square). Plotted in $A$ and $B$ is the fraction of maximum ${ }^{125} \mathrm{I}$-Bgt bound, i.e., ${ }^{125} \mathrm{I}$-Bgt bound in the presence of ligand divided by ${ }^{125} \mathrm{I}$-Bgt bound in the absence of ligand, as a function of ligand concentration. The line through the points represents a least-squares fit to the data of the equation: fraction of maximum ${ }^{125} \mathrm{I}-\mathrm{Bgt}$ bound $=($ Max. $) /(1+$ ([ligand] $\left.\left./ \mathrm{IC}_{50}\right)\right)^{\mathrm{n}}$, where ${ }^{\mathrm{n}}$ is the Hill coefficient and Max. is the maximum fitted value. The results for all experiments are summarized in Table 2. $B$, Inhibition of the initial rate of ${ }^{125} \mathrm{I}$-Bgt binding to cell-surface $\alpha 7 / 5 \mathrm{HT} 3$ homomers by the agonists ACh (solid circle), carbachol (solid square), nicotine (solid diamond), cytisine (solid triangle), and the antagonists MLA (open triangle) and dTC (open square).

conclude that the antagonists bind to the different sites on the PC12 cell BgtRs and $\alpha 7 / 5$ HT3 homomers with the same affinity.

\section{PC12 and homomeric BgtR agonist binding sites} are distinguishable

The two agonist binding sites on the Torpedo AChR were shown to be distinguishable by reduction of the receptor and specific alkylation of free sulfhydryl at the agonist binding site with an agonist such as bromoACh (Damle et al., 1978; Moore and Raftery, 1979; Wolosin et al., 1980). To test whether agonist binding sites on PC12 BgtRs and $\alpha 7 / 5 \mathrm{HT} 3$ homomers could be distinguished, we reduced and alkylated BgtR agonist binding sites. PC12 BgtRs were reduced with $0.5 \mathrm{~mm}$ DTT and then exposed to increasing concentrations of bromoACh. Only $\sim 80 \%$ of the ${ }^{125} \mathrm{I}$-Bgt binding sites could be alkylated and blocked by
bromoACh with an $\mathrm{IC}_{50}$ of $3.5 \times 10^{-6} \mathrm{M}$, whereas $20 \%$ of the sites retained the ability to bind ${ }^{125} \mathrm{I}-\mathrm{Bgt}$ (Fig. $7 A$ ). Approximately $75 \%$ of the ${ }^{125} \mathrm{I}$-Bgt sites on $\alpha 7 / 5 \mathrm{HT} 3$ homomers were alkylated and blocked by bromoACh with an $\mathrm{IC}_{50}$ of $2.5 \times 10^{-5} \mathrm{M}$, whereas $25 \%$ of the sites retained the ability to bind ${ }^{125} \mathrm{I}-\mathrm{Bgt}$ (Fig. $7 B$ ). Thus, thiol modification of PC12 cell BgtRs and $\alpha 7 / 5 \mathrm{HT} 3$ homomers reveals two classes of agonist binding sites on both receptors. If there were only two agonist sites per BgtR, there should be a 1:1 ratio of alkylated to unalkylated sites, as observed for the Torpedo AChR. We find a ratio of 4:1 for the PC12 BgtR and 3:1 for the $\alpha 7 / 5$ HT3 homomer, which provides additional evidence that there are at least three agonist sites per receptor and is more consistent with four or five agonist sites per receptor.

Because the population of ${ }^{125} \mathrm{I}$-Bgt sites that retained the ability to bind ${ }^{125} \mathrm{I}-\mathrm{Bgt}$ after exposure to bromoACh was relatively small, additional experiments were performed to test this result. In contrast to Torpedo AChRs, both agonist sites on skeletal muscle AChRs can be alkylated by agonists after reduction (Froehner et al., 1977). Using an identical protocol with mouse muscle $\alpha 1_{2} \beta 1 \epsilon \delta$ AChRs expressed in a mouse fibroblast cell line, we found that both sites on these AChRs could be alkylated, i.e., $\sim 100 \%$ of the ${ }^{125} \mathrm{I}$-Bgt sites were alkylated and blocked by bromoACh $\left[\mathrm{IC}_{50}\right.$ of $3.1 \times 10^{-8} \mathrm{M}($ Fig. $7 C$ )]. This result indicates that the unalkylated agonist sites on the PC12 and $\alpha 7 / 5 \mathrm{HT} 3$ cells were not artifacts of our protocol attributable to such potential problems as the reoxidation of the disulfide bond after removal of the DTT. Another concern was that the concentration of DTT was insufficient to reduce all of the PC12 cell BgtR sites. This possibility was tested by determining the fraction of sites alkylated by bromoACh after reduction with varying DTT concentrations (Fig. $7 D$ ). For the PC12 BgtRs, $\sim 20 \%$ of the agonist sites could not be alkylated by bromoACh, even at DTT concentrations as high as $10 \mathrm{~mm}$. For the mouse AChRs, virtually all sites were alkylated by bromoACh at $0.3 \mathrm{~mm}$.

\section{DISCUSSION}

\section{Characteristics of PC12 BgtRs}

In this study, we have characterized cell-surface BgtRs from the PC12 cell variant N21 (Burry, 1993). Most of the previous characterizations of neuronal BgtRs used brain preparations, principally chick brain preparation. Although these preparations are rich sources of BgtRs, they express at least two BgtR subtypes (Schoepfer et al., 1990; Gotti et al., 1992, 1994). Furthermore in these earlier studies, cells were solubilized with detergent, and the preparation contained both intracellular and cell-surface BgtRs. The study of BgtRs in the N21-PC12 cell line avoids these problems. The PC12 cell line appears to express a homogeneous class of BgtRs, which enabled us to perform our studies on intact living cells with the receptors in their native conformation. Thus, the pharmacologic measurements, the ${ }^{125} \mathrm{I}-\mathrm{Bgt}$ and bromoACh cross-linking experiments, and the electrophysiologic measurements were all performed on cell-surface receptors from the same PC12 cell line.

The conclusion that the PC12 cells express a single BgtR subtype is based on several observations. The best evidence was provided by the experiments in which cross-linking of the cellsurface BgtRs resulted in a single band on a gel (Fig. 4B), the size of which corresponded well with the measured sedimentation coefficient of the receptor (Fig. 4A). Additional evidence for a single subtype came from competition experiments between different cholinergic ligands and Bgt for the receptor (Fig. 6). These 
Table 2. Estimated $\mathrm{IC}_{50}$ values and Hill coefficients based on inhibition of Bgt binding to cell surface PC12, $\alpha 7 / 5 \mathrm{HT} \mathrm{T}_{3}$ and mouse muscle receptors by different cholinergic ligands

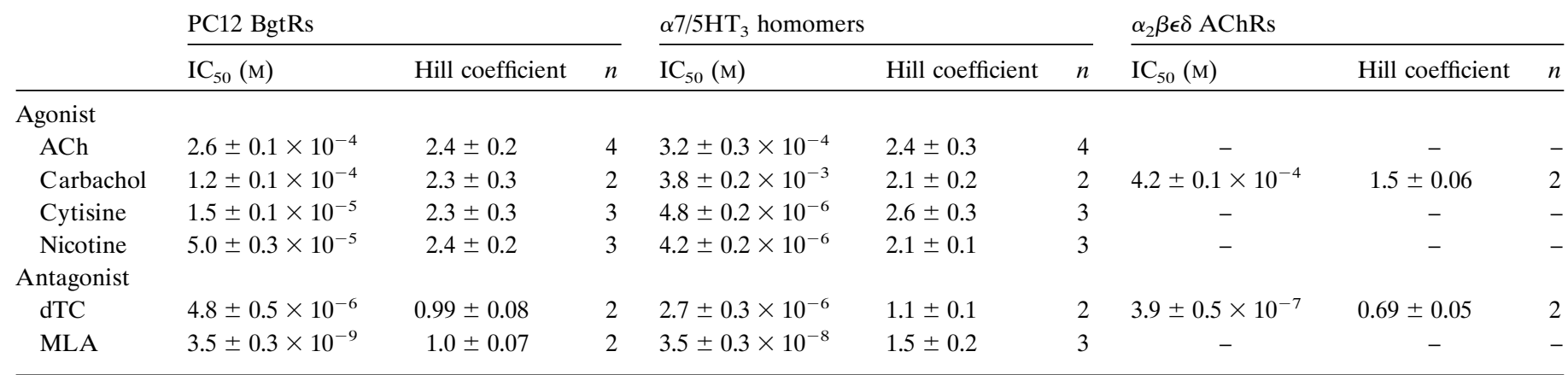

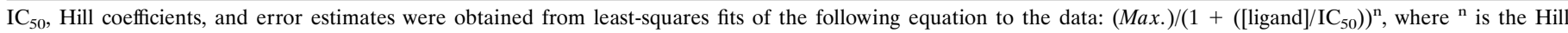
coefficient (see Fig. $7 A, B$ ). $n$ is the number of separate experiments.

experiments were consistent with a single set of sites and, therefore, a single BgtR subtype.

Characterization of PC12 cell BgtRs demonstrates that these receptors are functional nicotinic AChRs, containing $\alpha 7$ subunits, similar to chick BgtRs from ciliary ganglion cells (Vernallis et al., 1993; Zhang et al., 1994) and human BgtRs from Imr32 neuroblastoma cells (Gotti et al., 1995). The whole-cell response to nicotine is consistent with a single BgtR subtype, because the current is blocked almost completely by BgtR antagonists. The $10 \%$ of the current elicited by nicotine that was not blocked by either Bgt or MLA may represent the $\alpha 3 \beta 2$ AChR subtype, which is expressed at low levels in undifferentiated PC12 cells (Whiting et al., 1987; Henderson et al., 1994), but see Rogers et al. (1992) for an exception.

\section{Failure to express $\alpha 7$ homomers}

Expression of $\alpha 7$ subunits in Xenopus oocytes results in the assembly and cell-surface delivery of functional BgtRs (Couturier et al., 1990; Seguela et al., 1993; Peng et al., 1994). As assayed by ${ }^{125} \mathrm{I}$-Bgt binding, transfection of $\alpha 7$ cDNAs from three different species resulted in little to no cell-surface expression of BgtRs (Fig. 2A). One possible explanation for our failure to express significant amounts of $\alpha 7$-containing BgtRs is that the cell lines lacked one or more subunits needed for proper assembly in the more stringent mammalian expression system. Recent studies that reported successful expression of $\alpha 7$ subunits are at odds with this possibility. In two studies, the $\alpha 7$ cDNA was transfected into a human neuroblastoma cell line or PC12 cells, resulting in a sizable increase in the number of cell-surface BgtRs (Puchacz et al., 1994; Cooper and Millar, 1997). Although it is possible that the cells express other BgtR subunits, only a single subunit band corresponding to the $\alpha 7$ subunit was observed on SDS-PAGE gels, indicating that most BgtRs were $\alpha 7$ homomers. It seems more likely that PC12 and neuroblastoma cells have additional elements needed to properly process $\alpha 7$ subunits into homomers. In another study, $\alpha 7$ homomers were expressed when human $\alpha 7$ subunits were stably expressed in HEK 293 cells (Gopalakrishnan et al., 1995). The difference between that study and our attempts to express human $\alpha 7$ subunits is that they screened and selected among a number of stably transfected clonally isolated cells. Our poor expression levels can be explained if only a few of the cells properly processed $\alpha 7$ subunits into homomers.

\section{The agonist binding sites}

Marked differences were observed in the apparent affinities of different agonist for PC12 cell BgtRs and $\alpha 7 / 5 \mathrm{HT} 3$ homomers
(Table 2). Given the difference in the amino acid sequences of the rat $\alpha 7$ subunit and the chicken $\alpha 7 /$ mouse 5HT3 chimeric subunit, this result is not surprising even assuming that the PC12 BgtR is an $\alpha 7$ subunit homomer. What is surprising was the finding that the Hill coefficients fall in the range of 2.1-2.6. The data indicate that PC12 cell BgtRs and $\alpha 7 / 5$ HT3 homomers contain the same number of agonist binding sites and that the number of sites is at least three. Changes in the Hill coefficient can track the number of ligand binding sites accurately. Glycine receptors composed of only the ligand binding $\alpha$ subunits had a Hill coefficient of 4.2, consistent with a pentameric structure and five $\alpha$ subunits (Bormann et al., 1993). Different glycine receptors, composed of ligand binding $\alpha$ and structural $\beta$ subunits, had a Hill coefficient of 2.5 , consistent with three ligand binding sites and the presumed stoichiometry of $\alpha 3 \beta 2$ (Langosch et al., 1988). We would expect similar differences in the Hill coefficient of PC12 cell BgtRs and $\alpha 7 / 5 \mathrm{HT} 3$ homomers if they had a different number of ligand binding subunits.

Additional evidence about the number of agonist binding sites on PC12 cell BgtRs and $\alpha 7 / 5$ HT3 homomers was obtained by alkylation of the receptors with bromoACh. BromoACh was unable to alkylate all of the sites on each receptor: the ratio of alkylated to unalkylated sites was 4:1 for the PC12 cell BgtR and 3:1 for the $\alpha 7 / 5 \mathrm{HT} 3$ homomer. These data are consistent with four or five agonist sites per receptor. Our results with the $\alpha 7 / 5$ HT3 homomer are also consistent with electrophysiologic data indicating that $\alpha 7$ homomers expressed in Xenopus oocytes have five MLA binding sites (Palma et al., 1996).

Previous work on Torpedo membrane preparations has characterized in detail the alkylation of the AChR binding sites by different ligands. The residues alkylated by the affinity labeling were identified as adjacent disulfide-linked cysteine residues Cys 192 and 193 (Kao et al., 1984; Kao and Karlin, 1986). An adjacent pair of cysteines, homologous to those on Torpedo $\alpha 1$ subunits, is found on the $\alpha 7$ subunits and are presumably the residues on the PC12 cell BgtRs and $\alpha 7 / 5$ HT3 homomers that are labeled by bromoACh. Additional evidence indicating that the BgtR alkylated sites are similar to that of the muscle-type AChR is that the DTT dependence of the alkylation is almost identical for the two receptor types (Fig. 7D).

In this paper, we have demonstrated that the PC12 cell BgtR contains $\alpha 7$ subunits (Fig. $1 B$ ), sediments at $10 \mathrm{~S}$ on sucrose gradients (Fig. $4 A$ ) and has a molecular weight of $\sim 300 \mathrm{kDa}$ (Fig. $4 B$ ). These results together with our data showing that the PC12 cell BgtR contains at least three, and more likely four or five, 

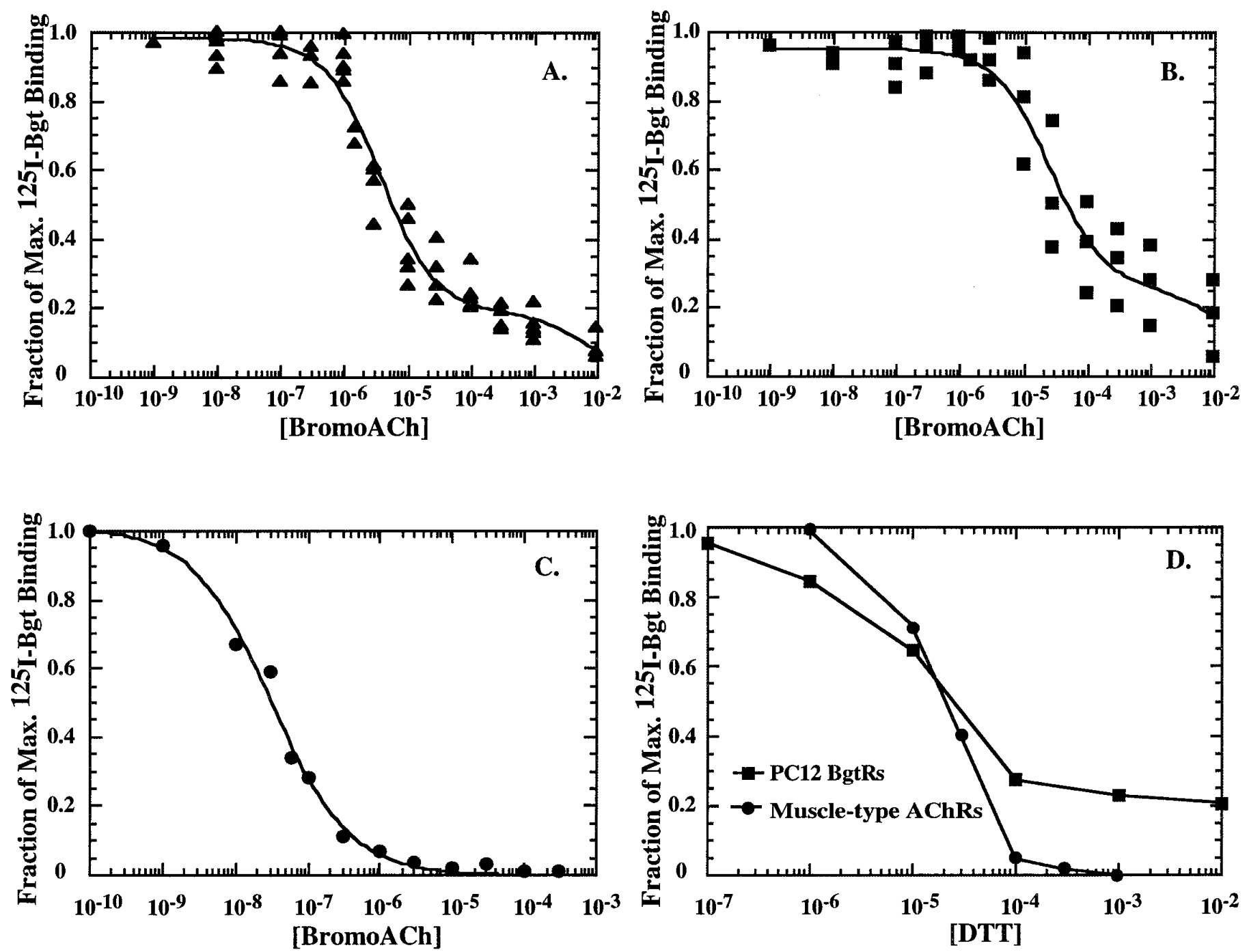

Figure 7. BromoACh alkylation of PC12 BgtRs and $\alpha 7 / 5 \mathrm{HT} 3$ homomers. A, BromoACh alkylation of PC12 BgtRs. Before cell-surface ${ }^{125} \mathrm{I}-\mathrm{Bgt}$ binding, PC12 cells were first treated with $0.5 \mathrm{~mm}$ DTT followed by the indicated concentration of bromoACh. The fraction of maximum ${ }^{125} \mathrm{I}-\mathrm{Bgt}$ bound as a function of bromoACh concentration is plotted in the figure. Shown are the data from five separate experiments in which each data point is the mean of two determinations. The data could not be fit by a single-site binding isotherm. The line through the points represents a least-squares fit to the equation: fraction of maximum ${ }^{125} \mathrm{I}$-Bgt bound $=A\left(1 /\left(1+\left([\right.\right.\right.$ bromoACh $\left.\left.] / \mathrm{IC}_{50} 1\right)\right)+B\left(1 /\left(1+\left(\left[\right.\right.\right.\right.$ bromoACh$\left.\left._{/} / \mathrm{IC}_{50} 2\right)\right)$, where $\mathrm{IC}_{50} 1$ and $\mathrm{IC}_{50} 2$ are $\mathrm{IC}_{50}$ values for two separate binding sites, and $A$ and $B$ are the fraction of total sites for each of the two sites. From the fit to the data, $80 \%$ of the surface toxin binding sites are alkylated by increasing concentrations of bromoACh with an $\mathrm{IC}_{50}$ of $3.5 \times 10^{-6} \mathrm{M}$. Twenty percent of the sites are relatively insensitive to reduction and alkylation. $B$, BromoACh alkylation of $\alpha 7 / 5 \mathrm{HT} 3$ homomers. Cells expressing $\alpha 7 / 5 \mathrm{HT} 3$ homomers were treated as in $A$ to alkylate the $\alpha 7 / 5 \mathrm{HT} 3$ homomers with bromoACh. The fraction of maximum ${ }^{125} \mathrm{I}$-Bgt bound as a function of bromoACh concentration is plotted in the figure. Data from three separate experiments are shown in which each data point is the mean of two determinations. Like the PC12 cells, the data could not be fit by a single-site binding isotherm. The line through the points represents a least-squares fit to the same equation as in $A$. From the fit to the data, $75 \%$ of the ${ }^{125} \mathrm{I}$-Bgt binding sites were alkylated by bromoACh with an $\mathrm{IC}_{50}$ of $2.5 \times 10^{-5} \mathrm{M}$, whereas $25 \%$ were insensitive. $C$, BromoACh alkylation of muscle-type AChRs. Cells stably expressing the $\alpha 1_{2} \beta 2 \epsilon \delta$ AChR subtype were treated as in $A$ and $B$ to alkylate the AChR with bromoACh. The fraction of maximum ${ }^{125} \mathrm{I}$-Bgt bound as a function of bromoACh concentration is plotted in the figure. Each data point is the mean of two determinations. Unlike PC12 BgtRs and $\alpha 7 / 5 \mathrm{HT} 3$ homomers, all muscle AChR Bgt binding sites were equally sensitive to bromoACh alkylation. The data were well fit by the equation: fraction of maximum ${ }^{125} \mathrm{I}$-Bgt bound $=\operatorname{Max} .\left(1 /\left(1+\left([\right.\right.\right.$ bromoACh $\left.\left.] / \mathrm{IC}_{50}\right)\right)$ with a fitted $\mathrm{IC}_{50}$ value of $3.1 \times 10^{-8} \mathrm{M}_{\text {. }}$ $D$, The DTT dependence of bromoACh alkylation. For both the PC12 cells and the cells expressing muscle-type AChRs, the concentration of DTT was varied over the indicated concentration range before the bromoACh alkylation and ${ }^{125} \mathrm{I}$-Bgt binding assay. After incubation in the indicated DTT concentration, the PC12 cells were incubated with $300 \mu \mathrm{M}$ bromoACh and the cells expressing muscle-type AChRs with $10 \mu \mathrm{M}$. The fraction of maximum ${ }^{125} \mathrm{I}-\mathrm{Bgt}$ bound as a function of DTT concentration is plotted in the figure. Each data point is the mean of two determinations.

ligand binding sites suggest that the PC12 BgtR is a pentamer of $\alpha 7$ subunits. This picture of neuronal BgtRs contradicts a number of studies in which BgtRs, purified primarily from chicken preparations, appear to contain two to four different polypeptide subunits (Conti et al., 1985; Kemp et al., 1985; Whiting and Lindstrom, 1987; Hermans-Borgmeyer et al., 1988; Schoepfer et al., 1990; Gotti et al., 1994). Several possibilities may explain the differences. First, BgtRs in the chicken brain are heterogenous (Schoepfer et al., 1990; Gotti et al., 1994). The chick brain expresses the $\alpha 8$ subunit, which is highly homologous to the $\alpha 7$ subunit isoform but has a higher molecular weight (Schoepfer et al., 1990). $\alpha 8$ subunits can assemble into BgtRs with or without $\alpha 7$ subunits in a tissue-specific manner (Keyser et al., 1993). Thus, one simple explanation of multiple subunit bands found in chick 
brain may be the presence of multiple BgtR subtypes in the preparation. Second, the $\mathrm{N}$ terminus of a molecular band smaller than the mature $\alpha 7$ subunit was shown to be identical to the $\mathrm{N}$ terminus of the $\alpha 7$ subunit (Conti et al., 1985). This raises the possibility that the BgtR preparations from brain were contaminated by proteolytic fragments of the $\alpha 7$ subunit. Finally, partially processed as well as fully processed $\alpha 7$ subunits, i.e., $\alpha 7$ subunits of different molecular weights, may have been purified from the solubilized brain preparation, because there was no effort to isolate cell-surface from intracellular BgtRs. Evidence that the $\alpha 7$ subunit is processed post-translationally is that it has three potential glycosylation sites and that it binds to both concanavalin A (Gotti et al., 1992) and wheat germ agglutinin (HermansBorgmeyer et al., 1988). Therefore, previous data characterizing the subunit composition of BgtRs do not exclude the possibility that the BgtR is a pentamer of $\alpha 7$ subunits.

\section{How does a homomeric receptor form distinguishable agonist binding sites?}

Our finding that bromoACh was unable to alkylate all of the BgtR binding sites indicates that the agonist binding sites are structurally different. Similar results on muscle-type AChRs has led to the conclusion that the differences observed for the two agonist binding sites on these receptors arise because the two $\alpha 1$ subunits interface with different subunits, either the $\gamma$ or $\delta$ subunits (Blount and Merlie, 1989; Pedersen and Cohen, 1990; Sine and Claudio, 1991). Clearly, a different mechanism must cause any structural differences in the agonist binding sites of the $\alpha 7 / 5$ HT3 homomer, because all five subunits are identical. One possibility is that a subset of $\alpha 7 / 5 \mathrm{HT} 3$ subunits undergoes different post-translational processing. Possible post-translational modification of these subunits includes N-linked glycosylation, disulfide bond formation, proline isomerization, and phosphorylation. Any differential processing of the subunits could produce two classes of $\alpha 7 / 5$ HT3 subunits, which in turn could lead to distinguishable ligand binding sites. Alternatively, two classes of $\alpha 7 /$ 5HT3 subunits could be created because of differences in subunit folding. If the biogenesis of $\alpha 7$ subunits is similar to that of $\alpha 1$ subunits, then the Bgt and agonist binding sites form after their synthesis (Merlie and Lindstrom, 1983) and during assembly of the pentamer (Green and Claudio, 1993). Perhaps these sites are forming on only some of the $\alpha 7$ subunits, and both ligand binding and structural subunits could be generated from the same gene product.

\section{REFERENCES}

Alkondon M, Albuquerque EX (1993) Diversity of nicotinic acetylcholine receptors in rat hippocampal neurons. I. Pharmacological and functional evidence for distinct structural subtypes. J Pharmacol Exp Ther 265:1455-1473.

Alkondon M, Pereira EF, Wonnacott S, Albuquerque EX (1992) Blockade of nicotinic currents in hippocampal neurons defines methyllycaconitine as a potent and specific receptor antagonist. Mol Pharmacol 41:802-808.

Alkondon M, Rocha ES, Maelicke A, Albuquerque EX (1996) Diversity of nicotinic acetylcholine receptors in rat brain. V. alpha-Bungarotoxinsensitive nicotinic receptors in olfactory bulb neurons and presynaptic modulation of glutamate release. J Pharmacol Exp Ther 278:1460-1471.

Anand R, Conroy WG, Schoepfer R, Whiting P, Lindstrom J (1991) Neuronal nicotinic acetylcholine receptors expressed in Xenopus oocytes have a pentameric quaternary structure. J Biol Chem 266:11192-11198.

Anand R, Peng X, Lindstrom J (1993) Homomeric and native alpha 7 acetylcholine receptors exhibit remarkably similar but non-identical pharmacological properties, suggesting that the native receptor is a heteromeric protein complex. FEBS Lett 327:241-246.

Barnard EA (1992) Receptor classes and the transmitter-gated ion channels. Trends Biochem Sci 17:368-374.

Blount P, Merlie JP (1989) Molecular basis of the two nonequivalent ligand binding sites of the muscle nicotinic acetylcholine receptor. Neuron 3:349-357.

Bormann J, Rundstrom N, Betz H, Langosch D (1993) Residues within transmembrane segment M2 determine chloride conductance of glycine receptor homo- and hetero-oligomers. EMBO J 12:3729-3737.

Boyd RT (1994) Sequencing and promoter analysis of the genomic region between rat neuronal nicotinic acetylcholine receptor $\beta 4$ and $\alpha 3$ genes. J Neurobiol 25:960-973.

Burry RW (1993) Nerve growth factor stimulates GAP-43 expression in PC12 cell clones independently of neurite outgrowth. J Neurosci Res $36: 241-251$.

Clarke PB (1992) The fall and rise of neuronal alpha-bungarotoxin binding proteins. Trends Pharmacol Sci 13:407-413.

Claudio T (1992) Stable expression of heterologous multisubunit protein complexes established by calcium phosphate or lipid mediated cotransfection. In: Methods in enzymology: ion channels (Rudy B, Iverson LE, eds), pp 391-408. San Diego: Academic.

Claudio T, Green WN, Hartman DS, Hayden D, Paulson HL, Sigworth FJ, Sine SM, Swedlund A (1987) Genetic reconstitution of functional acetylcholine receptor channels in mouse fibroblasts. Science 238:1688-1694.

Conti TB, Dunn SM, Barnard EA, Dolly JO, Lai FA, Ray N, Raftery MA (1985) Brain and muscle nicotinic acetylcholine receptors are different but homologous proteins. Proc Natl Acad Sci USA 82:5208-5212.

Cooper E, Couturier S, Ballivet M (1991) Pentameric structure and subunit stoichiometry of a neuronal nicotinic acetylcholine receptor. Nature 350:235-238.

Cooper ST, Millar NS (1997) Host cell-specific folding and assembly of the neuronal nicotinic acetylcholine receptor alpha 7 subunit. J Neurochem 68:2140-2151.

Corringer PJ, Galzi JL, Eisele JL, Bertrand S, Changeux JP, Bertrand D (1995) Identification of a new component of the agonist binding site of the nicotinic alpha 7 homooligomeric receptor. J Biol Chem 270:11749-11752.

Couturier S, Bertrand D, Matter JM, Hernandez MC, Bertrand S, Millar N, Valera S, Barkas T, Ballivet M (1990) A neuronal nicotinic acetylcholine receptor subunit (alpha 7) is developmentally regulated and forms a homo-oligomeric channel blocked by alpha-BTX. Neuron 5:847-856.

Damle VN, McLaughlin M, Karlin A (1978) Bromoacetylcholine as an affinity label of the acetylcholine receptor from Torpedo californica. Biochem Biophys Res Commun 84:845-851.

Eisele JL, Bertrand S, Galzi JL, Devillers TA, Changeux JP, Bertrand D (1993) Chimaeric nicotinic-serotonergic receptor combines distinct ligand binding and channel specificities. Nature 366:479-483.

Elgoyhen AB, Johnson DS, Boulter J, Vetter DE, Heinemann S (1994) Alpha 9: an acetylcholine receptor with novel pharmacological properties expressed in rat cochlear hair cells. Cell 79:705-715.

Froehner SC, Karlin A, Hall ZW (1977) Affinity alkylation labels two subunits of the reduced acetylcholine receptor from mammalian muscle. Proc Natl Acad Sci USA 74:4685-4688.

Gething MJ, McCammon K, Sambrook J (1989) Protein folding and intracellular transport: evaluation of conformational changes in nascent exocytotic proteins. Methods Cell Biol 32:185-206.

Gopalakrishnan M, Buisson B, Touma E, Giordano T, Campbell JE, Hu IC, Donnelly RD, Arneric SP, Bertrand D, Sullivan JP (1995) Stable expression and pharmacological properties of the human alpha 7 nicotinic acetylcholine receptor. Eur J Pharmacol 290:237-246.

Gotti C, Hanke W, Schlue WR, Briscini L, Moretti M, Clementi F (1992) A functional alpha-bungarotoxin receptor is present in chick cerebellum: purification and characterization. Neuroscience 50:117-127.

Gotti C, Hanke W, Maury K, Moretti M, Ballivet M, Clementi F, Bertrand D (1994) Pharmacology and biophysical properties of alpha 7 and alpha 7-alpha 8 alpha-bungarotoxin receptor subtypes immunopurified from the chick optic lobe. Eur J Neurosci 6:1281-1291.

Gotti C, Briscini L, Verderio C, Oortgiesen M, Balestra B, Clementi F (1995) Native nicotinic acetylcholine receptors in human Imr32 neuroblastoma cells: functional, immunological and pharmacological properties. Eur J Neurosci 7:2083-2092.

Gray R, Rajan AS, Radcliffe KA, Yakehiro M, Dani JA (1996) Hip- 
pocampal synaptic transmission enhanced by low concentrations of nicotine. Nature 383:713-716.

Green WN, Claudio T (1993) Acetylcholine receptor assembly: subunit folding and oligomerization occur sequentially. Cell 74:57-69.

Hamill OP, Marty A, Neher E, Sakmann B, Sigworth FJ (1981) Improved patch-clamp techniques for high-resolution current recordings from cells and cell-free membrane patches. Pflügers Arch 391:85-100

Henderson LP, Gdovin MJ, Liu C-L, Gardner PD, Maue RA (1994) Nerve growth factor increases nicotinic $\mathrm{ACh}$ receptor gene expression and current density in wild-type and protein kinase A-deficient PC12 cells. J Neurosci 14:1153-1163.

Hermans-Borgmeyer I, Sawruk E, Schlob P, Gundelfinger ED, Betz H (1988) Biochemical and molecular biology approaches to central nicotinic acetylcholine receptors. In: Nicotinic Acetylcholine Receptors in the Nervous System (Clementi FEA, ed), pp 78-88. Heidelberg: Springer.

Kao PN, Karlin A (1986) Acetylcholine receptor binding site contains a disulfide cross-link between adjacent half-cystinyl residues. J Biol Chem 261:8085-8088.

Kao PN, Dwork AJ, Kaldany RRJ, Silver M, Wideman J, Stein J, Karlin A (1984) Identification of the $\alpha$-subunit half cysteine specifically labeled by an affinity reagent for acetylcholine receptor binding site. J Biol Chem 259:11662-11665.

Karlin A, Akabas MH (1995) Towards a structural basis for the function of nicotinic acetylcholine receptors and their cousins. Neuron 15:1231-1244.

Kemp G, Bentley L, McNamee MG, Morley BJ (1985) Purification and characterization of the alpha-bungarotoxin binding protein from rat brain. Brain Res 347:274-283.

Keyser KT, Britto LR, Schoepfer R, Whiting P, Cooper J, Conroy W, Brozozowska PA, Karten HJ, Lindstrom J (1993) Three subtypes of alpha-bungarotoxin-sensitive nicotinic acetylcholine receptors are expressed in chick retina. J Neurosci 13:442-454.

Langosch D, Thomas L, Betz H (1988) Conserved quaternary structure of ligand-gated ion channels: the postsynaptic glycine receptor is a pentamer. Proc Natl Acad Sci USA 85:7394-7398.

Lindstrom J, Anand R, Peng X, Gerzanich V, Wang F, Li Y (1995) Neuronal nicotinic receptor subtypes. Ann NY Acad Sci 757:100-116.

Margolskee RF, McHendry-Rinde B, Horn R (1993) Panning transfected cells for electrophysiological studies. Biotechniques 15:906-911.

McGehee DS, Role LW (1995) Physiological diversity of nicotinic acetylcholine receptors expressed by vertebrate neurons. [Review]. Annu Rev Physiol 57:521-546.

McGehee DS, Heath MJS, Gelber S, Devay P, Role LW (1995) Nicotine enhancement of fast excitatory synaptic transmission in CNS by presynaptic receptors. Science 269:1692-1696.

Merlie JP, Lindstrom J (1983) Assembly in vivo of mouse muscle acetylcholine receptor: identification of an alpha subunit species that may be an assembly intermediate. Cell 34:747-757.

Moore H-P, Raftery MA (1979) Studies of reversible and irreversible interactions of an alkylating agonist with Torpedo californica acetylcholine receptor in membrane-bound and purified states. Biochemistry 18:1862-1867.

Neubig RR, Cohen JB (1979) Equilibrium binding of $\left[{ }^{3} \mathrm{H}\right]$ tubocurarine and $\left[{ }^{3} \mathrm{H}\right]$ acetylcholine by Torpedo postsynaptic membranes: stoichiometry and ligand interactions. Biochemistry 18:5464-5475.

Palma E, Bertrand S, Binzoni T, Bertrand D (1996) Neuronal nicotinic $\alpha 7$ receptor expressed in Xenopus oocytes present five putative binding sites for methyllycaconitine. J Physiol (Lond) 491.1:151-161.

Patrick J, Stallcup WB (1977) $\alpha$-Bungarotoxin binding and cholinergic receptor function on a rat sympathetic nerve line. $\mathrm{J}$ Biol Chem 252:8629-8633.

Pedersen SE, Cohen JB (1990) D-Tubocurarine binding sites are located at alpha-gamma and alpha-delta subunit interfaces of the nicotinic acetylcholine receptor. Proc Natl Acad Sci USA 87:2785-2789.
Peng X, Katz M, Gerzanich V, Anand R, Lindstrom J (1994) Human alpha 7 acetylcholine receptor: cloning of the alpha 7 subunit from the SH-SY5Y cell line and determination of pharmacological properties of native receptors and functional alpha 7 homomers expressed in Xenopus oocytes. Mol Pharmacol 45:546-554.

Popot J-L, Changeux J-P (1984) Nicotinic receptor of acetylcholine: structure of an oligomeric integral membrane protein. Physiol Rev 64:1162-1239.

Puchacz E, Buisson B, Bertrand D, Lukas RJ (1994) Functional expression of nicotinic acetylcholine receptors containing rat alpha 7 subunits in human SH-SY5Y neuroblastoma cells. FEBS Lett 354:155-159.

Rogers SW, Mandelzys A, Deneris ES, Cooper E, Heinemann S (1992) The expression of nicotinic acetylcholine receptors by PC12 cells treated with NGF. J Neurosci 12:4611-4623.

Role LW (1992) Diversity in primary structure and function of neuronal nicotinic acetylcholine receptor channels. Curr Opin Neurobiol 2:254-462.

Role LW, Berg DK (1996) Nicotinic receptors in the development and modulation of CNS synapses. Neuron 16:1077-1085.

Sargent P (1993) The diversity of neuronal nicotinic acetylcholine receptors. Annu Rev Neurosci 16:403-443.

Schoepfer R, Conroy WG, Whiting P, Gore M, Lindstrom J (1990) Brain alpha-bungarotoxin binding protein cDNAs and MAbs reveal subtypes of this branch of the ligand-gated ion channel gene superfamily. Neuron 5:35-48.

Seguela P, Wadiche J, Dineley MK, Dani JA, Patrick JW (1993) Molecular cloning, functional properties, and distribution of rat brain alpha 7: a nicotinic cation channel highly permeable to calcium. J Neurosci 13:596-604.

Sine SM, Claudio T (1991) $\gamma$ - And $\delta$-subunits regulate the affinity and the cooperativity of ligand binding to the acetylcholine receptor. J Biol Chem 266:19369-19377.

Sine SM, Taylor P (1981) Relationship between reversible antagonist occupancy and the functional capacity of the acetylcholine receptor. J Biol Chem 256:6692-6699.

Swick AG, Janicot M, Cheneval KT, McLenithan JC, Lane MD (1992) Promoter-cDNA-directed heterologous protein expression in Xenopus laevis oocytes. Proc Natl Acad Sci USA 89:1812-1816.

Unwin N (1993) Neurotransmitter action: opening of ligand-gated ion channels. Cell 72(suppl):31-41.

Vernallis AB, Conroy WG, Berg DK (1993) Neurons assemble acetylcholine receptors with as many as three kinds of subunits while maintaining subunit segregation among receptor subtypes. Neuron 10:451-464.

Ward JM, Cockcroft VB, Lunt GG, Smillie FS, Wonnacott S (1990) Methyllycaconitine: a selective probe for neuronal alpha-bungarotoxin binding sites. FEBS Lett 270:45-48.

Whiting PJ, Lindstrom JM (1986) Purification and characterization of a nicotinic acetylcholine receptor from chick brain. Biochemistry 25:2082-2093.

Whiting PJ, Lindstrom J (1987) Purification and characterization of a nicotinic acetylcholine receptor from rat brain. Proc Natl Acad Sci USA 84:595-599.

Whiting PJ, Schoepfer R, Swanson LW, Simmons DM, Lindstrom JM (1987) Functional acetylcholine receptor in PC12 cells reacts with a monoclonal antibody to brain nicotinic receptors. Nature 327:515-518.

Wolosin JM, Lyddiatt A, Dolly JO, Barnard EA (1980) Stoichiometry of the ligand-binding sites in the acetylcholine-receptor oligomer from muscle and from electric organ. Eur J Biochem 109:495-505.

Zhang ZW, Vijayaraghavan S, Berg DK (1994) Neuronal acetylcholine receptors that bind alpha-bungarotoxin with high affinity function as ligand-gated ion channels. Neuron 12:167-177. 